\title{
Anthropogenic impact in the Santa Maria di Leuca cold-water coral province (Mediterranean Sea): Observations and conservation straits
}

\author{
G. D’Onghia a,*, C. Calculli ${ }^{\mathrm{b}}$, F. Capezzuto ${ }^{\mathrm{a}}$, R. Carlucci ${ }^{\mathrm{a}}$, A. Carluccio ${ }^{\mathrm{a}}, \mathrm{A}$. Grehan ${ }^{\mathrm{c}}$, \\ A. Indennidate ${ }^{\text {a }}$, P. Maiorano ${ }^{\text {a }}$, F. Mastrototaro ${ }^{a}$, A. Pollice ${ }^{\text {b }}$, T. Russo ${ }^{d}$, A. Savini ${ }^{\text {e }}$, L. Sion ${ }^{\text {a }}$, \\ A. Tursi ${ }^{\mathrm{a}}$ \\ a Department of Biology, University of Bari Aldo Moro, LRU CoNISMa, Bari, Italy \\ ${ }^{\mathrm{b}}$ Department of Economics and Mathematics, University of Bari Aldo Moro, Bari, Italy \\ ${ }^{\mathrm{c}}$ Department of Earth and Ocean Sciences, National University of Ireland, Galway, Ireland \\ d Laboratory of Experimental Ecology and Aquaculture - Department of Biology, "Tor Vergata" University of Rome, Italy \\ e Department of Earth and Environmental Sciences, University of Milano-Bicocca, LRU CoNISMa, Milano, Italy
}

\section{A R T I C L E I N F O}

Keywords:

Cold-water coral

Fisheries Restricted Area

Fishery

Anthropogenic impact

Conservation

Mediterranean

\begin{abstract}
A B S T R A C T
The Santa Maria di Leuca (SML) cold-water coral (CWC) province is a proposed priority conservation area according to several conservation initiatives in the Mediterranean Sea. Part of it is a Fisheries Restricted Area (FRA). Anthropogenic impacts due to fishing on this FRA were investigated using a towed camera system during 2005. The geographic distribution of fishing effort in the SML CWC province was examined through an observers' program of longline and trawl fishing activities during 2009 and 2010 and Vessel Monitoring by satellite System (VMS) data from 2008 to 2013. Using the video system, it was possible to observe evidence of impacts in the FRA due to longlines, proved by remains of lines on the bottoms and/or entangled in corals, and those due to trawl nets, proved by trawl door scars on the bottom. The application of Generalized Liner Models indicates that the impacts due to longline were significantly related to a geographic site characterized by carbonate mounds while those from trawl net were significantly related to the soft bottoms, consisting of bioturbated fine-grained sediments. The presence of waste of various types was also observed in the FRA; plastic was the most widespread waste and was significantly related to a macrohabitat characterized by the presence of corals.

The geographic distribution of fishing effort for each type of fishing were rather superimposed in the two years of the observers' program and six years of VMS data with a significantly greater fishing effort outside the FRA than inside this area. The trawlers generally fished on the muddy bottoms of the upper and middle slope within the SML CWC province and near and inside the northward limit of the FRA. The longliners fished mainly on the shelf in north and off the FRA. The coral by-catch was only recorded during 2009 in $26 \%$ of the trawl hauls. No coral by-catch was recorded from longlining in either year. The catches from longlining mainly consisted of Chelidonichthys lucerna, Merluccius merluccius and Conger conger while those from trawling mostly consisted of Aristeus antennatus, Aristaeomorpha foliacea and M. merluccius. The information collected during the observers' program and VMS data indicated greater impact due to trawling than longlining. The conservation and effective management of this vulnerable marine ecosystem remain difficult.
\end{abstract}

(c) 2016 Elsevier Ltd. All rights reserved.

\section{Introduction}

Cold-water coral (CWC) communities represent extensive threedimensional habitats that host a variety of faunal associations and are used for shelter, feeding, spawning and as nursery areas by valuable fish and invertebrates of commercial interest (e.g. Freiwald

\footnotetext{
* Corresponding author.

E-mail address: gianfranco.donghia@uniba.it (G. D’Onghia).
}

et al., 2004; Tursi et al., 2004; Roberts et al., 2009; Buhl-Mortensen et al., 2010; D’Onghia et al., 2010; Baillon et al., 2012; Henry et al., 2013). For these reasons these habitats are impacted by commercial fishing (e.g. Rogers, 1999; Roberts et al., 2000; Fosså et al., 2002; Hall-Spencer et al., 2002; Reed, 2002; Grehan et al., 2005; Wheeler et al., 2005; Buhl-Mortensen et al., 2010; Söffker et al., 2011; Fabri et al., 2014), generating a widespread alarming scientific consensus on the need for their protection and conservation. In fact, due to the slow recovery rates of corals, the habitats that they build are highly vulnerable (e.g. Roberts, 2002; Morgan et al., 2005; DeVogelaere 
et al., 2005; Brock et al., 2009; Hourigan, 2009; Buhl-Mortensen et al., 2010; Orejas et al., 2011a, 2011b; Lartaud et al., 2014). In this respect, CWC have been included on the lists of Vulnerable Marine Ecosystems (VME) (FAO, 2009) for which conservation constitutes a global priority. Furthermore, since corals may provide Essential Fish Habitat (EFH) for commercial fish and invertebrates (Mortensen et al., 2005; Roberts et al., 2009; Mastrototaro et al., 2010; Baillon et al., 2012; Henry et al., 2013), their protection could combine biodiversity conservation and fisheries management objectives according to the Ecosystem Approach to Fisheries (EAF) (Garcia et al., 2003).

The impact of fishing on deep-sea coral communities has mainly been documented in the Atlantic (e.g. Rogers, 1999; Roberts et al., 2000; Duncan, 2001; Fosså et al., 2002; Hall-Spencer et al., 2002; Reed, 2002; Grehan et al., 2005; Mortensen et al., 2005; Wheeler et al., 2005; Durán Muñoz et al., 2011; Söffker et al., 2011; Sampaio et al., 2012). However, some studies on this issue have also been carried out in the Mediterranean (Orejas et al., 2009; Madurell et al., 2012; Bo et al., 2014a, 2014b; Fabri et al., 2014; Savini et al., 2014). The obvious impact of trawling on coral communities is the mechanical damage caused by otter boards and nets that destroy the three-dimensional structure of coral colonies (Hall-Spencer, 2001; Buhl-Mortensen et al., 2010). Video surveys carried out off West Norway show that deep-water coral reefs are reduced to rubble by towed fishing gear (Hall-Spencer; 2001). Other fishing gears, such as longlines and gillnets, can also cause damage to coral reefs since they cause breakage of the colonies (Lumsden et al., 2007; Orejas et al., 2009; Durán Muñoz et al., 2011; D’Onghia et al., 2012; Sampaio et al., 2012; Bo et al., 2014a). Furthermore, bottom trawl activity alters the hydrodynamic and sedimentary conditions, indirectly affecting corals and the associated benthic fauna (Puig et al., 2012); in fact, coral species, like all suspension feeders, are particularly vulnerable to the effects of increased sedimentation (Rogers, 1999; Purser, 2015 and references therein).

Deep-sea coral communities characterized by the species Madrepora oculata and Lophelia pertusa are also located in the deep waters of the Mediterranean Sea but their distribution is still incompletely known (Freiwald et al., 2009; Orejas et al., 2009; Lo Iacono et al., 2012; Gori et al., 2013; Mytilineou et al., 2014; Angeletti et al., 2014). These coral communities live at temperatures ranging from $12.9^{\circ} \mathrm{C}$ to $13.9^{\circ} \mathrm{C}$ close to the upper limit for many CWCs living at bathyal depths (Freiwald et al., 2009). Thus, CWCs in the Mediterranean do not flourish as they do in the Atlantic and their occurrence in the Mediterranean appears to be a relic of a much more extensive distribution during the Pleistocene (Pérès, 1985; Taviani et al., 2005; Wienberg et al., 2009). In addition to limiting hydrological conditions, the Mediterranean CWC

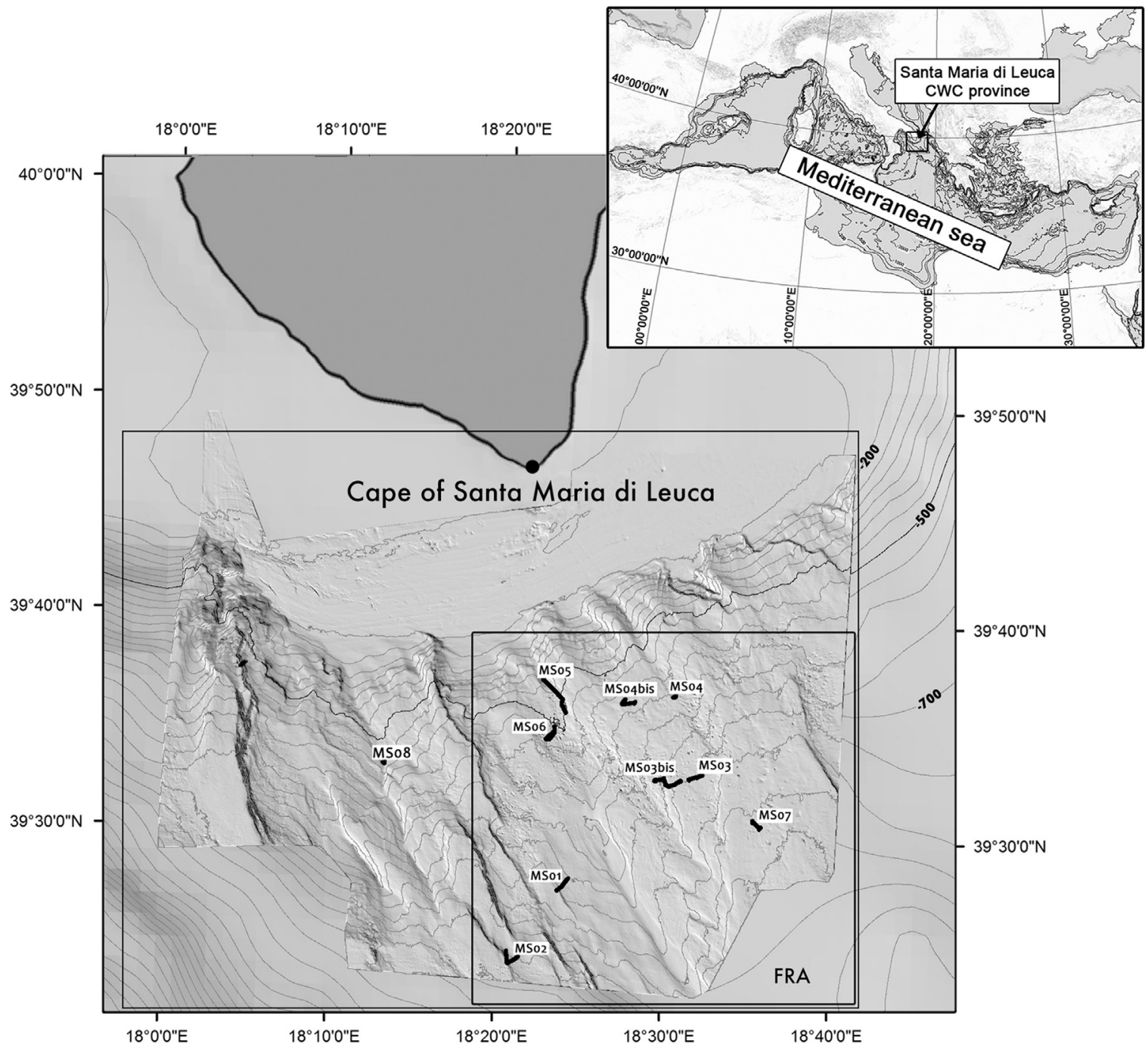

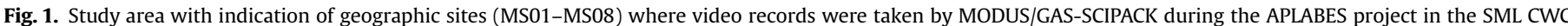
province inside and outside the FRA (Fisheries Restricted Area). Universal Transverse Mercator (UTM) projection (Zone 32 North with WGS84 datum). 
communities are also subject to various anthropogenic activities, such as fishing and dumping of litter (Orejas et al., 2009; Coll et al., 2010; D’Onghia et al., 2010; Indennidate et al., 2010; RamirezLlodra et al., 2011; Madurell et al., 2012; Bo et al., 2014a; Fabri et al., 2014; Savini et al., 2014).

The Santa Maria di Leuca (SML) CWC province represents an example of living Madrepora-Lophelia-bearing coral mounds in the Mediterranean Sea (Tursi et al., 2004; Freiwald et al., 2009; Mastrototaro et al., 2010). Considering the impact of trawling and, to a lesser extent, of other fishing gears on deep-sea coral communities, in January 2006 the General Fisheries Commission for the Mediterranean (GFCM) created the new legal category of "Fisheries Restricted Area" (FRA) (Fig. 1). The FRA covers a part of the SML CWC province. Towed dredges and bottom trawl nets have been prohibited in the FRA. Members are required to call the attention of the appropriate authorities in order to protect this FRA from the impact of any other activity jeopardizing the conservation of the features that characterize the particular habitat (GFCMRAC/SPA, 2007). Although trawling is formally illegal, unauthorized operations may still take place. In fact, after the establishment of the FRA, Indennidate et al. (2010) recorded trawling activity inside the northward limit of the FRA and Savini et al. (2014) recorded trawling traces in the coral community.

The "deep-sea corals" habitat is reported on the list of priority habitats present in Italy (Relini and Tursi, 2009) according to the SPA/BIO protocol (Barcelona Convention) and the SML CWC province is also included among the selected areas of conservation interest in the open sea, including deep sea (Specially Protected Areas of Mediterranean Importance) (SPAMIs) (UNEP-MAP RAC/ SPA, 2009, 2010; de Juan et al., 2012). The criteria of rarity, importance for life history stages of species, importance for threatened and endangered species/habitats, vulnerability, biological diversity and naturalness, make this ecosystem a Sensitive Habitat (SH) (de Juan and Lleonart, 2010). In this respect, the SML CWC province is included in the proposed conservation plan of "Vulnerable habitats" (de Juan and Lleonart, 2010). In addition, this Mediterranean CWC area is also among the proposed priority conservation areas according to several conservation initiatives (e.g. UNEP MAP EBSA; CIESM/Mediterranean Marine Peace Parks; Oceana/MedNet) (Oceana, 2011; Micheli et al., 2013).

The objective of this study is to provide a contribution to the knowledge of the fishing activity in this CWC province and anthropogenic impact in the FRA where mounds covered with corals are mainly distributed in international waters. Three types of data have been used in this work: video records, direct fishery observations and Vessel Monitoring by satellite System (VMS). The first type of data was taken during the APLABES project (Corselli, 2010); the second was collected during the observers' program carried out in the context of the CoralFISH EU 7FP project (Indennidate et al., 2010); the third type of data has been provided by the Ministero delle Politiche Agricole Alimentari e Forestali (MIPAAF) - Direzione Generale Pesca, which is the owner and user in the Data Collection Framework for Fisheries Sector (http://ec. europa.eu/fisheries/cfp/fishing_rules/data_collection/index_en.

htm). The second and third type of data were used in order to provide exact locations of the commercial fishing operations and allow the assessment of whether fishing gears are deployed on coral mounds and sensitive beds or on neighboring sedimentary bottoms outside the FRA. All the relevant results are presented in relation to the present knowledge of the SML CWC province and the relevant conservation perspectives for this rare and fragile ecosystem.

\section{Materials and methods}

\subsection{Study area, biodiversity and fishery resources}

The SML CWC province, located along the Apulian margin, a few miles off Cape Santa Maria di Leuca in the Northern Ionian Sea (Central Mediterranean) (Fig. 1), is the widest and deepest known deep-sea coral community in the Mediterranean (Freiwald et al., 2009; Corselli, 2010). Living colonies of M. oculata and L. pertusa have been collected between 425 and $1100 \mathrm{~m}$ in depth in the SML CWC province (Tursi et al., 2004; Mastrototaro et al., 2010). The westernmost presence of both M. oculata and L. pertusa in the SML CWC province was recorded by Freiwald et al. (2009) using QUEST4000 Remotely Operated Vehicle (ROV) during the HERMES $\mathrm{R} / \mathrm{V}$ Meteor M70-1 cruise. This presence refers to a vertical escarpment which forms the eastern wall of a major canyon system. Live Madrepora and Lophelia have been recorded at depths between 670 and $744 \mathrm{~m}$ and 603-744 m, respectively (Freiwald et al., 2009). Savini et al. (2014) have carried out habitat mapping as part of the CoralFISH (www.eu-fp7-coralfish.net) and MAGIC (www.magicproject.it) projects, providing indications of complex topographic features over an area of about $2000 \mathrm{~km}^{2}$ between about 120 and $1400 \mathrm{~m}$ in depth, including the Gallipoli escarpment surveyed by Freiwald et al. (2009). The presence of CWCs recorded by Freiwald et al. (2009) is far out to the west of the FRA, confirming that this FRA covers only the eastern part of the SML CWC province.

The benthic and benthopelagic fauna distributed in the SML CWC province has been investigated using different sampling techniques, from dredge to various fishing gears, from ROV to a lander equipped with video cameras (Tursi et al., 2004; Longo et al., 2005; Carlier et al., 2009; D’Onghia et al., 2010; Mastrototaro et al., 2010; D’Onghia et al., 2011; Capezzuto et al., 2012; D'Onghia et al., 2012; Mastrototaro et al., 2013, 2014). Indeed, the SML deepsea coral ecosystem represents a Mediterranean deep-water biodiversity "hotspot" which also plays an important role as a nursery and spawning area for several benthopelagic commercial species (Tursi et al., 2004; Mastrototaro et al., 2010, D’Onghia et al., 2010, 2011, 2012). To date a total of 257 species have been recorded in the SML CWC province (D'Onghia et al., 2015 and references therein). The complex seabed topography of the whole SML coral province (especially where CWC occur), with the presence of fault escarpments, arcuate head-scarps indenting the shelf break, compression and extension ridges, mass-wasting deposits, coralmounds, hardgrounds and canyons (Savini et al., 2014), makes this area unsuitable for safe commercial fishing. In fact, there is evidence of attraction-refuge effects inside the coral area and fishing effects outside (D’Onghia et al., 2010).

The most important ground-fish resources are represented by the deep-water shrimps (Aristeus antennatus and Aristaeomorpha foliacea) which can constitute up to about $60 \%$ in weight and $66 \%$ in economic value of the total catch (Carlucci et al., 2003; D'Onghia et al., 2005, 2009). Other important ground-fish resources are hake (Merluccius merluccius), greater forkbeard (Phycis blennoides), rockfish (Helicolenus dactylopterus), deep water rose shrimp (Parapenaeus longirostris) and the Norway lobster (Nephrops norvegicus) which can often provide an important contribution to the whole catch (Tursi et al., 1994, 1998; D’Onghia et al., 1998, 2003; Capezzuto et al., 2010; Maiorano et al., 2010). Some other commercial deep-water species found in the area are anglerfish (Lophius piscatorius and Lophius budegassa) and golden shrimps Plesionika heterocarpus, Plesionika edwardsii and Plesionika martia (Maiorano et al., 2002; Carlucci et al., 2009). The horned octopus (Eledone cirrhosa) and squids, such as Illex coindetii and Todaropsis eblanae, are the main cephalopod species caught by the trawl nets (Tursi and D'Onghia, 1992). Longliners target hake, greater 
forkbeard, blackspot seabream (Pagellus bogaraveo), bluntnose sixgill shark (Hexanchus griseus), piper (Trigla lyra), tub gurnard (Chelidonichthys lucerna), European conger (Conger conger), silver scabbardfish (Lepidopus caudatus) and wreckfish (Polyprion americanus) (D’Onghia et al., 2000; Carbonara et al., 2003; Indennidate et al., 2010; Capezzuto et al., 2010; Maiorano et al., 2010; D’Onghia et al., 2012).

The presence of corals is known to the local fishermen who experienced gear damage and losses, but they often fish close to this area with the aim of catching large specimens. The habitat related specific behavior of some fishes is used by fishermen to target particular species. In fact, those working off Cape SML state that the coral area is an attractive fishing ground for large individuals of blackspot seabream (D'Onghia et al., 2010, 2012).

\subsection{Analysis of video records from APLABES project}

Video observations were carried out using the GAS-SCIPACK module connected to the MODUS vehicle (hereafter reported as MGS) (Fig. S1), towed by the R/V UNIVERSITATIS during May 2005, at 10 geographic sites of the SML coral province (Etiope et al., 2010; Vertino et al., 2010) (Fig. 1). The MODUS vehicle was equipped with horizontal and vertical thrusters and an umbilical cable providing power supply and data transmission. The videos examined herein were recorded by a video-camera (Deep Sea Power and Light MULTI-SEACAM 2050 and DL 1040) mounted at the base ("bottom camera") of the GAS-SCIPACK module. This camera was oriented vertically. Video recordings were made during daylight hours. Only actual survey time ( $32 \mathrm{~h} 45 \mathrm{~min}$ from a total of $44 \mathrm{~h}$ ) was included in the present analysis, which excludes the time spent when the MGS was in the water column very distant from the bottom or was out of focus and clouded by sediment. Since the MGS system was not equipped with a proper underwater positioning system, the survey track of this system was extrapolated from the offset position of its cable at sea in relation to the vessel DGPS antenna (Vertino et al., 2010; D’Onghia et al., 2011). Since the system did not have a continuous size calibration tool, a $10 \mathrm{~cm}$ long 'yellow tube' was attached by a $2 \mathrm{~m}$ long rope to the MGS frame. This helped in evaluating the width of the field of view. This width was multiplied by the length of the MGS track in order to obtain the surface area explored.

The mean, minimum and maximum depths as well as the geographic coordinates and surface area explored for each site are reported in Table 1. Two of these sites (MS04-Atlantis Mound and MS06-Yellow Chain) were accurately mapped and described in Vertino et al. (2010). In each of them, a total of 7 main benthic macrohabitats were identified according to these authors (op. cit.): 1-CF: Coral Framework; 2-LCF: Loose Coral Framework; 3-CF/H: Coral Framework and Hardground; 4-H: Hardground crusts and boulders; 5-CR: Coral Rubble; 6-BR: Buried Rubble; 7-BS: Bioturbated fine-grained Sediment. The video recordings were used to identify and quantify fishing impact on each benthic macrohabitat identified at each geographic site. In addition to the impact of fishing, the presence of waste was also recorded and quantified. The various typologies identified were classified as: can (C), cloth $(\mathrm{Cl})$, glass $(\mathrm{Gl})$, plastic $(\mathrm{P})$ and mixed $(\mathrm{M})$. The examined areas (expressed in $\mathrm{m}^{2}$ ) by geographic site and macrohabitat are reported in Table 2 .

In order to evaluate the differences in the observed fishing impacts between geographic sites and macrohabitats in the FRA, including the MS08 geographic site, logistic regression was used to model data related to each gear. The same method was applied to data concerning the number of wastes as total and as plastic material. The logistic regression models (or logit models) are Generalized Linear Models, GLMs (Agresti, 2002) with binomial errors and logit link and are used to describe the relationship between a dichotomous response and a set of predictors. For the case study, the number of impacts of both longline and trawl data, as well as the number of wastes, were converted into presence/ absence variables, thus identifying observations in which fishing impacts or wastes were recorded. Given the probability of the presence of fishing impact or waste $p=\operatorname{Pr}(Y=1 \mid X=x)$ for the i-th observation, the logistic regression model is formally given by:

$\log \operatorname{it}\left(p_{i}\right)=\log \left(\frac{p_{i}}{1-p_{i}}\right)=+\beta_{0}+\beta_{1} x_{i, h}+\beta_{2} x_{i, s} i=1, \ldots n$

where $\beta_{0}$ is an intercept term, $\beta_{1}, \beta_{2}$ are regression coefficients to be estimated associated to $x_{h}$ and $x_{s}$ factors which indicate the macrohabitat and the geographic site of the i-th observation, respectively. Logistic models were performed by means of the $\mathrm{glm}$ ( ) function of the R software (R Core Team, 2014).

\subsection{Observers' program from the CoralFISH project}

The fisheries belonging to the marine administrative district of Gallipoli (Compartimento Marittimo di Gallipoli) operate to the North-West of the SML coral province (D'Onghia et al., 2010). The SML fishery is a small one consisting of about seven or eight trawlers and one or two longliners, all smaller than 10 gross tonnage, as well as about 10 small-scale fishing boats operating mostly with trammel nets in coastal waters. Fishing occurs from Monday to Friday during day-light hours only. Both trawlers and longliners generally work on daily trips; they set off at 03.00$04.00 \mathrm{~h}$ in the morning and return to harbor at $15.00-16.00 \mathrm{~h}$ or at $18.00-19.00 \mathrm{~h}$ in winter and summer, respectively. Commercial hauls are carried out at different depths, generally from 100 to $800 \mathrm{~m}$. Fishing is not allowed at night or weekends.

Table 1

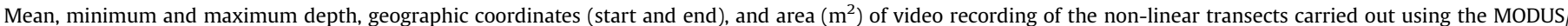
GAS-SCIPACK system inside and outside the FRA during the APLABES project.

\begin{tabular}{|c|c|c|c|c|c|c|c|c|}
\hline \multirow[b]{2}{*}{ Site } & \multicolumn{3}{|c|}{ Depth (m) } & \multicolumn{2}{|l|}{ Start } & \multicolumn{2}{|l|}{ End } & \multirow[t]{2}{*}{ Area $\left(\mathbf{m}^{2}\right)$} \\
\hline & Mean & Min & Max & Latitude & Longitude & Latitude & Longitude & \\
\hline MS01 & 759 & 729 & 819 & $39^{\circ} 27.296^{\prime} \mathrm{N}$ & $18^{\circ} 25.298^{\prime} \mathrm{E}$ & $39^{\circ} 27.643^{\prime} \mathrm{N}$ & $18^{\circ} 23.789^{\prime} \mathrm{E}$ & 5265.09 \\
\hline MSO2 & 1143 & 1102 & 1179 & $39^{\circ} 24.461^{\prime} \mathrm{N}$ & $18^{\circ} 21.484^{\prime} \mathrm{E}$ & $39^{\circ} 24.767^{\prime} \mathrm{N}$ & $18^{\circ} 20.856^{\prime} \mathrm{E}$ & 1384.94 \\
\hline MS03 & 790 & 775 & 810 & $39^{\circ} 33.106^{\prime} \mathrm{N}$ & $18^{\circ} 32.138^{\prime} \mathrm{E}$ & $39^{\circ} 32.914^{\prime} \mathrm{N}$ & $18^{\circ} 31.501^{\prime} \mathrm{E}$ & 2263.11 \\
\hline MS03 bis & 771 & 717 & 804 & $39^{\circ} 32.827^{\prime} \mathrm{N}$ & $18^{\circ} 30.994^{\prime} \mathrm{E}$ & $39^{\circ} 32.858^{\prime} \mathrm{N}$ & $18^{\circ} 29.510^{\prime} \mathrm{E}$ & 1760.86 \\
\hline MS04 & 648 & 631 & 663 & $39^{\circ} 36.761^{\prime} \mathrm{N}$ & $18^{\circ} 30.571^{\prime} \mathrm{E}$ & $39^{\circ} 36.696^{\prime} \mathrm{N}$ & $18^{\circ} 30.378^{\prime} \mathrm{E}$ & 1131.32 \\
\hline MS04 bis & 629 & 613 & 634 & $39^{\circ} 36.463^{\prime} \mathrm{N}$ & $18^{\circ} 28.150^{\prime} \mathrm{E}$ & $39^{\circ} 36.513^{\prime} \mathrm{N}$ & $18^{\circ} 27.511^{\prime} \mathrm{E}$ & 1592.00 \\
\hline MS05 & 453 & 386 & 498 & $39^{\circ} 35.858^{\prime} \mathrm{N}$ & $18^{\circ} 24.027^{\prime} \mathrm{E}$ & $39^{\circ} 37.347^{\prime} \mathrm{N}$ & $18^{\circ} 22.636^{\prime} \mathrm{E}$ & 4363.19 \\
\hline MS06 & 519 & 495 & 556 & $39^{\circ} 35.207^{\prime} \mathrm{N}$ & $18^{\circ} 23.350^{\prime} \mathrm{E}$ & $39^{\circ} 35.015^{\prime} \mathrm{N}$ & $18^{\circ} 23.379^{\prime} \mathrm{E}$ & 4975.88 \\
\hline MS07 & 906 & 895 & 919 & $39^{\circ} 30.748^{\prime} \mathrm{N}$ & $18^{\circ} 35.736^{\prime} \mathrm{E}$ & $39^{\circ} 30.807^{\prime} \mathrm{N}$ & $18^{\circ} 35.671^{\prime} \mathrm{E}$ & 1180.87 \\
\hline MS08 & 542 & 547 & 539 & $39^{\circ} 33.269^{\prime} \mathrm{N}$ & $18^{\circ} 13.279^{\prime} \mathrm{E}$ & $39^{\circ} 33.316^{\prime} \mathrm{N}$ & $18^{\circ} 13.292^{\prime} \mathrm{E}$ & 636.69 \\
\hline
\end{tabular}


Table 2

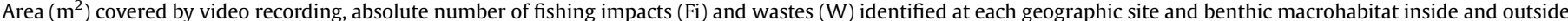

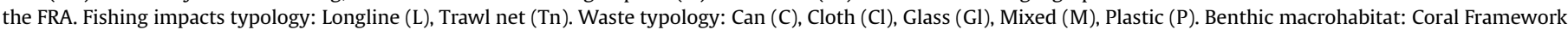

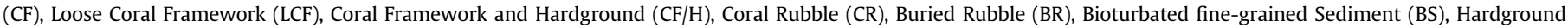
crusts and boulders $(H)$.

\begin{tabular}{|c|c|c|c|c|c|c|c|c|c|}
\hline \multirow[t]{2}{*}{ Geographic site } & & \multicolumn{7}{|c|}{ Benthic macrohabitat } & \multirow[t]{2}{*}{ Total } \\
\hline & & CF & LCF & $\mathrm{CF} / \mathrm{H}$ & CR & BR & BS & $\boldsymbol{H}$ & \\
\hline \multirow[t]{3}{*}{ MS01 } & $\mathrm{m}^{2}$ & - & 20.38 & 2.13 & - & 480.33 & 4728.79 & 33.46 & 5265.09 \\
\hline & $\mathrm{Fi}$ & - & 0 & 0 & - & $1 \mathrm{~L}$ & $1 \mathrm{Tn}$ & 0 & $1 \mathrm{~L} / 1 \mathrm{Tn}$ \\
\hline & W & - & $1 \mathrm{P}$ & 0 & $1 \mathrm{P}$ & $1 \mathrm{Gl}$ & $1 \mathrm{C} / 1 \mathrm{Gl} / 2 \mathrm{P}$ & 0 & $1 \mathrm{C} / 2 \mathrm{Gl} / 4 \mathrm{P}$ \\
\hline \multirow[t]{3}{*}{ MS02 } & $\mathrm{m}^{2}$ & - & - & - & - & 683.82 & 664.13 & 37.00 & 1384.94 \\
\hline & $\mathrm{Fi}$ & - & - & - & - & 0 & 0 & 0 & $\mathbf{0}$ \\
\hline & $\mathrm{W}$ & - & - & - & - & $1 \mathrm{Gl}$ & 0 & 0 & 1Gl \\
\hline \multirow[t]{3}{*}{ MS03 } & $\mathrm{m}^{2}$ & 145.31 & 358.44 & 24.85 & 184.91 & 90.98 & 1433.76 & 24.85 & 2263.11 \\
\hline & $\mathrm{Fi}$ & 0 & $2 \mathrm{~L}$ & 0 & 0 & 0 & $1 \mathrm{Tn}$ & 0 & $2 L / 1 T n$ \\
\hline & $\mathrm{W}$ & 0 & $1 \mathrm{P}$ & $1 \mathrm{P}$ & 0 & 0 & 0 & 0 & $2 P$ \\
\hline \multirow[t]{3}{*}{ MS03 bis } & $\mathrm{m}^{2}$ & 22.08 & 75.18 & 5.37 & 90.70 & 34.01 & 1521.59 & 11.93 & 1760.86 \\
\hline & $\mathrm{Fi}$ & 0 & 0 & 0 & 0 & 0 & $1 \mathrm{~L} / 1 \mathrm{Tn}$ & 0 & 1L/1Tn \\
\hline & $\mathrm{W}$ & 0 & 0 & 0 & 0 & 0 & $2 \mathrm{P}$ & 0 & $2 P$ \\
\hline \multirow[t]{3}{*}{ MS04 } & $\mathrm{m}^{2}$ & 93.39 & 330.67 & 16.73 & 45.02 & 52.63 & 440.79 & 152.10 & 1131.32 \\
\hline & $\mathrm{Fi}$ & 0 & 0 & 0 & 0 & $1 \mathrm{~L}$ & 0 & 0 & $1 \mathrm{~L}$ \\
\hline & $\mathrm{W}$ & 0 & $4 \mathrm{P}$ & 0 & 0 & 0 & 0 & 0 & $4 P$ \\
\hline \multirow[t]{3}{*}{ MS04 bis } & $\mathrm{m}^{2}$ & - & 34.01 & - & 21.48 & 71.60 & 1454.75 & 10.14 & 1592.00 \\
\hline & $\mathrm{Fi}$ & - & 0 & - & 0 & $1 \mathrm{Tn}$ & $1 \mathrm{Tn}$ & 0 & $2 \operatorname{Tn}$ \\
\hline & $\mathrm{W}$ & - & 0 & - & $1 C$ & 0 & 0 & 0 & 1C \\
\hline \multirow[t]{3}{*}{ MS05 } & $\mathrm{m}^{2}$ & - & - & - & - & 3.77 & 4359.42 & & 4363.19 \\
\hline & $\mathrm{Fi}$ & - & - & - & - & 0 & $15 \mathrm{Tn}$ & - & 15Tn \\
\hline & $\mathrm{W}$ & - & - & - & - & 0 & $1 \mathrm{Gl}$ & - & $1 G I$ \\
\hline \multirow[t]{3}{*}{ MS06 } & $\mathrm{m}^{2}$ & 140.22 & 778.69 & 281.05 & 143.80 & 701.72 & 2737.66 & 192.73 & 4975.88 \\
\hline & $\mathrm{Fi}$ & 0 & $2 \mathrm{~L}$ & $2 \mathrm{~L}$ & $1 \mathrm{~L}$ & $3 \mathrm{~L}$ & $6 \mathrm{~L} / 2 \mathrm{Tn}$ & $2 \mathrm{~L}$ & $16 \mathrm{~L} / 2 \mathrm{Tn}$ \\
\hline & $\mathrm{W}$ & 0 & $3 \mathrm{Cl} / 1 \mathrm{M} / 10 \mathrm{P}$ & 0 & $1 \mathrm{P}$ & $1 \mathrm{Cl}$ & 0 & 0 & $4 \mathrm{Cl} / 1 \mathrm{M} / 11 \mathrm{P}$ \\
\hline \multirow[t]{3}{*}{ MS07 } & $\mathrm{m}^{2}$ & - & - & - & - & 660.55 & 520.32 & - & 1180.87 \\
\hline & $\mathrm{Fi}$ & - & - & - & - & 0 & 0 & - & $\mathbf{0}$ \\
\hline & $\mathrm{W}$ & - & - & - & - & 0 & 0 & - & $\mathbf{0}$ \\
\hline \multirow[t]{3}{*}{ MS08 } & $\mathrm{m}^{2}$ & - & 49.28 & - & 87.31 & 49.28 & 437.74 & 13.08 & 636.69 \\
\hline & $\mathrm{Fi}$ & - & 0 & - & 0 & 0 & $1 \mathrm{~L}$ & 0 & $1 \mathrm{~L}$ \\
\hline & $\mathrm{W}$ & - & $2 \mathrm{P}$ & 0 & 0 & 0 & $1 \mathrm{Gl}$ & 0 & 1GI/2P \\
\hline \multirow[t]{3}{*}{ Total } & $\mathrm{m}^{2}$ & 401.01 & 1646.66 & 330.13 & 573.22 & 2828.69 & 18298.95 & 475.30 & 24553.95 \\
\hline & $\mathrm{Fi}$ & $\mathbf{0}$ & $4 L$ & $2 \mathbf{L}$ & $1 \mathrm{~L}$ & $5 \mathrm{~L} / 1 \mathrm{Tn}$ & 8L/21Tn & $2 \mathbf{L}$ & $22 \mathrm{~L} / 22 \mathrm{Tn}$ \\
\hline & $\mathrm{W}$ & $\mathbf{0}$ & $3 C l / 1 M / 18 P$ & $1 P$ & $1 \mathrm{C} / 2 \mathrm{P}$ & $1 \mathrm{Cl} / 2 \mathrm{Gl}$ & $1 \mathrm{C} / 3 \mathrm{Gl} / 4 \mathrm{P}$ & $\mathbf{0}$ & $2 \mathrm{C} / 4 \mathrm{Cl} / 5 \mathrm{Gl} / 1 \mathrm{M} / 25 \mathrm{P}$ \\
\hline
\end{tabular}

- macrohabitat not observed.

Data for commercial fishing were collected from June to October during 2009 and 2010. These months were selected since the good sea-weather conditions allow vessels to fish on deep-sea bottoms more distant from the coast. Fishing effort and catch composition data were collected for longlines and trawl nets. The trawlers are equipped with the commercial bottom trawl net. The longliners are generally equipped with about $4 \mathrm{~km}$ of monofilament longline with about 700 hooks and snoods of $2.5 \mathrm{~m}$ in length. The type of hook employed is the J-hook 7 and they are usually baited with Sardina pilchardus. Fishermen deploy 3-4 longlines during each fishing day. Set time is generally between 3 and $5 \mathrm{~h}$ for each of them. The trawlers are equipped with a nylon otter-trawl net with $50 \mathrm{~mm}$ stretched mesh in the cod-end. The vessel speed during the tow is maintained at $2.5-2.8$ knots. Tow duration is around $4 \mathrm{~h}$.

Fishermen compiled effort and catch sheets prepared by the authors. Moreover, fishermen allowed additional on-board observations by authors every 15 days during fishing operations in order to monitor effort and catch data and to check compilation of the sheets. Fishing effort was measured as fishing days per month both for longliners and trawlers. In particular, fishing days per month was obtained by summing the number of working days of each vessel recorded each month in the SML fishery. The following effort-catch data were collected:

- fishing zone with indication of depth, latitude and longitude;

- date and time of fishing, set time in hours and number of hooks (if longliner), haul time (if trawler), sea-weather conditions;
- species captured, both commercial and discard, expressed as Catch Per Unit Effort (CPUE) in $\mathrm{kg} / 1000$ hooks for longlines and $\mathrm{kg} /$ hour for trawl nets;

- any by-catch of corals or other invertebrates.

Taking into account the depth range of fishing activity in the study area, three depth strata $(10-200 \mathrm{~m}$; 201-500 m; 501$800 \mathrm{~m}$ ) were considered in order to evaluate the distribution of fishing effort (hour) by depth for both longliners and trawlers.

In order to evaluate the differences in terms of fishing effort between areas inside and outside the FRA, a single-sample proportion test using the prop.test function of the $\mathrm{R}$ software was applied separately for each gear. The test calculates a chi-squared statistic that is equivalent to the traditional $z$-test of proportion. Given the total number of fishing hours inside and outside the FRA for each gear and for each year, we tested the null hypothesis that the proportion of minutes, inside the FRA over the total fishing time for each year was the same of that outside.

\subsection{Analysis of Vessel Monitoring by satellite System (VMS)}

In order to evaluate the amount of fishing activity in the SML fishery as well as in the FRA, an explorative analysis of vessels trajectories operating in the study area between 2008 and 2013 was conducted. Data were taken from the VMS, which was introduced in 2002 by the European Union (EC, 2002) and was mandatory for vessels with length over all (LOA) $\geq 24 \mathrm{~m}$; successively, the VMS was mandatory for LOA $\geq 18 \mathrm{~m}$ in 2004, for 



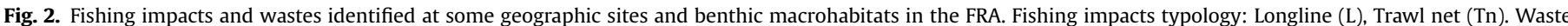

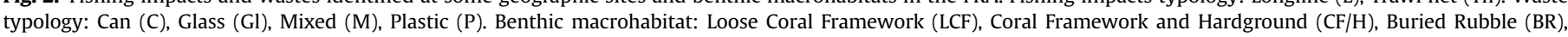
Bioturbated fine-grained Sediment (BS). 
$\mathrm{LOA} \geq 15 \mathrm{~m}$ in 2005 and for $\mathrm{LOA} \geq 12 \mathrm{~m}$ in 2012 (Russo et al., 2013). This kind of data concerned information about positions, speeds and courses of each vessel allowing a complete reconstruction of fishing activities in the area at both spatial and temporal scales. Standard procedures were applied for data cleaning, identification of fishing trips, and interpolation (Russo et al., 2011a). Furthermore, data were classified according to their fishing techniques (Level 4 Metier, corresponding to gear used, following the EU aggregation of Fishing Activity, available at http://eur-lex. europa.eu/LexUriServ/LexUriServ.do?uri=OJ:L:2008:346:0037:00 $88: E N$ :PDF\#page $=23$ ), using logbook and vessel register data (Russo et al., 2011b). At the end of these procedures, data concerning the Northern Ionian Sea and vessels that performed trawls (OTB) and longlines (LLS) were selected and hauls positions were identified using a speed filter. To ensure the representativeness of fishing activities in the area, fishing points were associated to a speed range of 2-3 knots for both OTB and LLS.

The purpose of the analysis was to produce a preliminary description of the fishing activities by calculating the number of vessels for each fishing technique and year operating in the area, as well as obtaining the spatial representations of the fishing effort.

The analysis was implemented using the $\mathrm{R}$ software ( $\mathrm{R}$ Core Team, 2014), especially by means of basic functions of the VMSbase R package (Russo et al., 2014), which represents a powerful tool for the high resolution analyses of fishing activity and quantitative evaluations of fishing effort.

\section{Results}

\subsection{Analysis of video records from APLABES project}

The fishing impact due to both longlines and trawl nets are widespread in the FRA (Table 2 and Fig. 2). The number of impacts due to longline was the same of those due to trawl net. The greatest number of longline remains standardised to unit area $\left(\mathrm{N} / 10 \mathrm{~m}^{2}\right)$ was observed at the MS06-Yellow Chain geographic site (Fig. 3A) which comprises several elongated reliefs up to $25 \mathrm{~m}$ high characterized by the presence of living coral colonies (Vertino et al., 2010). Other geographic sites where longline remains were observed are located in the northern-central areas (MS03, MS04) and outside the FRA (MS08). The application of the logistic regression models indicates that the impacts due to longline were significantly related to geographic sites (Table 3 ).

The impacts due to trawl nets are proved by trawl door scars on the bottom (Table 2 and Fig. 3A). The scars were mostly observed at MS05 (Fig. 3A) which is the northernmost geographic site mainly characterized by fine-grained sediment covering sediment blocks and more regular bottoms suitable for trawling. Other trawl net signs, standardised to unit area $\left(\mathrm{N} / 10 \mathrm{~m}^{2}\right)$, were shown in MS04bis and, to lesser extent, in MS03bis, MS03, MS06 and MS01 (Fig. 3A). The results of fitted logit models indicate that the impacts due to trawl net were significantly related to the habitat (Table 3), consisting in bioturbated fine-grained sediments (BS) (Table 2).

The presence of waste of various types was observed at almost all geographic sites; however, plastic was the most widespread waste (Table 2 and Fig. 3B). A glass bottle was also observed at a depth greater than $1100 \mathrm{~m}$ at MS02. However, the number of wastes in total was not significantly related to either geographic site or typology of macrohabitat (Table 3) while the number of plastic materials was significantly related to the habitat (Table 3), consisting in Loose Coral Framework (LCF) (Table 2).


Fig. 3. Area covered by video records $\left(\mathrm{m}^{2}\right)$ and standardized number $\left(\mathrm{N} / 10 \mathrm{~m}^{2}\right)$ of fishing impacts for each gear (longline and trawl net) (A) and standardized number of wastes (B) identified at different geographic sites inside and outside the FRA. Can (C), Cloth ( $\mathrm{Cl})$, Glass (Gl), Mixed (M), Plastic (P).

Table 3

ANOVA results of logistic regression models for fishing impacts (longline and trawl) and wastes data. $\mathrm{df}=$ degrees of freedom; $\mathrm{SS}=$ Sum of Squares; $\mathrm{MS}=$ Mean Square; $F=F$-statistic values

\begin{tabular}{lrllll}
\hline & df & SS & MS & $F$ & $p$-Value \\
\hline Longline & & & & & \\
Habitat & 6 & 0.443 & 0.074 & 0.636 & 0.700 \\
Site & 9 & 4.191 & 0.466 & 4.013 & $\mathbf{0 . 0 0 1}$ \\
Residual & 34 & 3.946 & 0.116 & & \\
Trawl & & & & & \\
Habitat & 6 & 2.720 & 0.453 & 6.826 & $<\mathbf{0 . 0 0 1}$ \\
Site & 9 & 1.042 & 0.116 & 1.743 & 0.117 \\
Residual & 34 & 2.256 & 0.066 & & \\
Waste & & & & & \\
Habitat & 6 & 2.438 & 0.406 & 2.033 & 0.088 \\
Site & 9 & 1.265 & 0.140 & 0.703 & 0.702 \\
Residual & 34 & 6.797 & 0.199 & & \\
Plastic & & & & & \\
Habitat & 6 & 2.718 & 0.453 & 3.842 & $\mathbf{0 . 0 0 5}$ \\
Site & 9 & 0.653 & 0.073 & 0.616 & 0.775 \\
Residual & 34 & 4.009 & 0.118 & & \\
\hline
\end{tabular}

\subsection{Observers' program from CoralFISH project}

A maximum of seven trawlers and one longliner were consistently recorded fishing in the SML fishery during 2009 and a maximum of four trawlers and one longliner during 2010. The number of fishing days per month varied largely throughout the investigated period according to the sea-weather conditions and to the fact that some vessels shifted their fishing activity towards the Gallipoli fishery (Table 4). The geographic distributions of fishing hauls were rather superimposed in the two years for each type of fishing (Figs. 4 and 5). The longliners fished mainly on the shelf $(<200 \mathrm{~m}$ ) and, to a lesser extent, between 200 and $500 \mathrm{~m}$, on a broad longitudinal gradient north of the FRA; it only carried out two hauls during 2010 in the FRA at depths greater than $500 \mathrm{~m}$ 
Table 4

Fishing effort in total number $(N)$ of days and vessels per month and gear recorded in SML fishery during the "Observers' Program".

\begin{tabular}{|c|c|c|c|c|c|c|c|c|c|c|}
\hline & June & & July & & August & & Septem & & Octobe & \\
\hline 2009 & $N$ days & $N$ vessels & $N$ days & $N$ vessels & $N$ days & $N$ vessels & $N$ days & $N$ vessels & $N$ days & $N$ vessels \\
\hline Trawl net & 32 & 4 & 46 & 7 & 29 & 6 & \multicolumn{2}{|c|}{ Closed season } & 18 & 3 \\
\hline \multicolumn{11}{|l|}{2010} \\
\hline Trawl net & 30 & 4 & 74 & 4 & 43 & 4 & \multicolumn{2}{|c|}{ Closed season } & 24 & 4 \\
\hline Longline & 4 & 1 & 12 & 1 & 13 & 1 & 11 & 1 & 2 & 1 \\
\hline
\end{tabular}

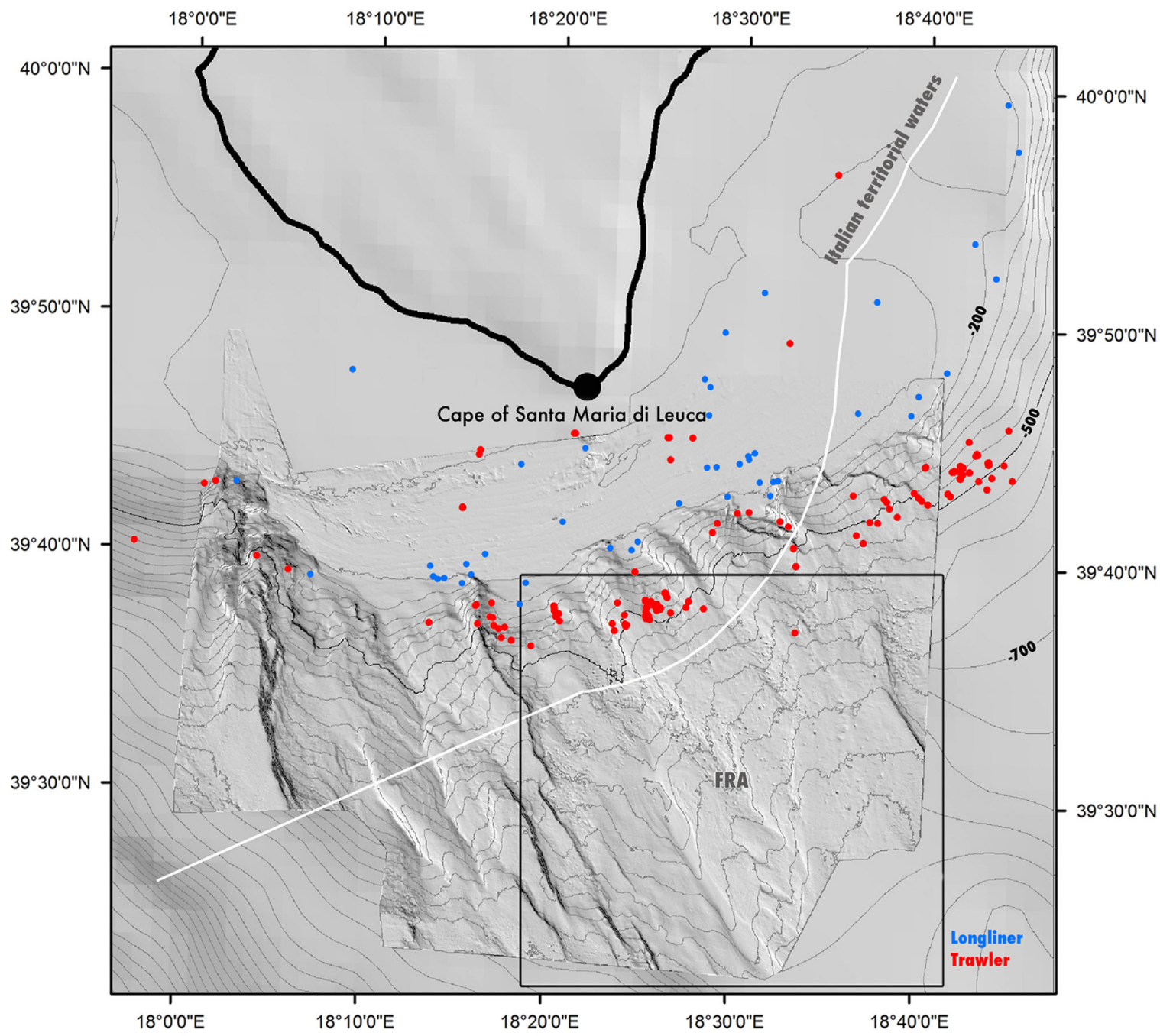

Fig. 4. Distribution of the fishing hauls recorded in the Santa Maria di Leuca fishery during the “Observers' Program” (2009).

(Figs. 5 and 6). The trawlers generally fished on the muddy bottoms near and inside the northward limit of the FRA (Figs. 4 and 5). Most of the trawl hauls were carried out between the upper and middle slope with a change of fishing time in the depth strata of $200-500 \mathrm{~m}$ and $500-800 \mathrm{~m}$ between 2009 and 2010 (Fig. 6). The proportion test indicates that the fishing effort was significantly greater outside the FRA for both gears and years (Table 5).

Average CPUE ( $\mathrm{kg} / \mathrm{h}$ and $\mathrm{kg} / 1000$ hooks) of the most abundant species obtained during 2009 and 2010 are presented in Fig. 7. The catches from trawling mostly consisted of $M$. merluccius, A. antennatus, I. coindetii, L. budegassa and A. foliacea in 2009 and A. antennatus, Hoplostethus mediterraneus (discard species) and $M$. merluccius in 2010 while those from longlining were mainly made up of C. lucerna, M. merluccius and C. conger in 2009 and M. merluccius, C. lucerna, C. conger and L. caudatus in 2010. The coral bycatch, mostly as fragments, was only recorded in $26 \%$ of the hauls from trawling during 2009. No coral by-catch was recorded from longlining in either year.

\subsection{Analysis of Vessel Monitoring by satellite System (VMS)}

The number of vessels for each fishing technique and year operating in the area is reported in Table 6. The spatial representations of the fishing effort (log transformed number of fishing hours) obtained from VMS data for both OTB and LLS is presented 




Fig. 5. Distribution of the fishing hauls recorded in the Santa Maria di Leuca fishery during the "Observers' Program" (2010).
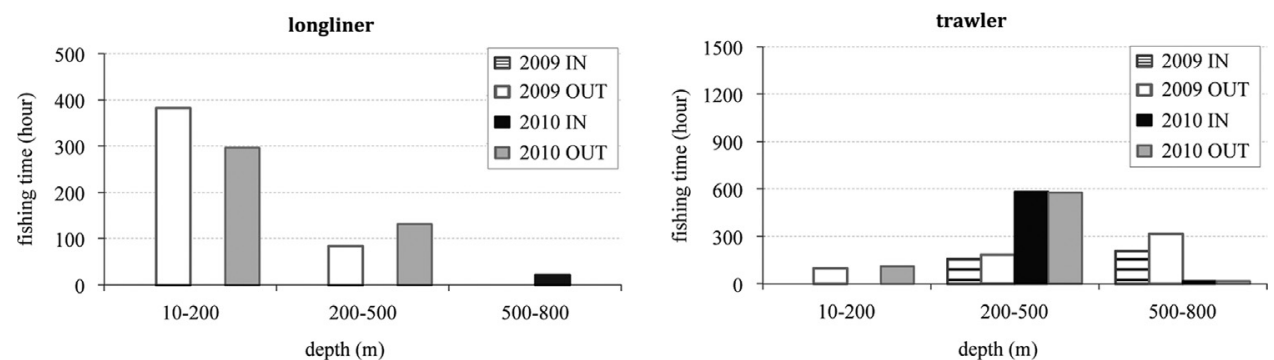

Fig. 6. Fishing time by depth stratum and year of longliners and trawlers recorded inside (IN) and outside (OUT) the FRA

in Fig. 8. The geographic distribution of fishing effort for each type of fishing were rather superimposed during the examined period (2008-2013). The trawlers generally fished at north and within the SML CWC province as well as near and inside the northward limit of the FRA. The longliners mainly fished on the shelf at north the SML CWC province and off the FRA.

\section{Discussion}

The results of this work regard data collected both before (video survey) and after (observers' program and VMS data) the institution of the FRA in the SML CWC province. During the video
Table 5

Results of proportion test for fishing time inside and outside the FRA $\left(H_{0}: \pi=0.5\right)$.

\begin{tabular}{lllllrl}
\hline & & estimated $\boldsymbol{\pi}$ & $\mathbf{9 5 \%}$ CI & & $\chi^{2}$ & $\boldsymbol{p}$-Value \\
\hline \multirow{2}{*}{2009} & Longline & 0.000 & 0.000 & 0.001 & 27960.00 & $<\mathbf{0 . 0 0 1}$ \\
& Trawl net & 0.381 & 0.000 & 0.384 & 3295.74 & $<\mathbf{0 . 0 0 1}$ \\
2010 & Longline & 0.048 & 0.000 & 0.049 & 22067.12 & $<\mathbf{0 . 0 0 1}$ \\
& Trawl net & 0.461 & 0.000 & 0.046 & 486.99 & $<\mathbf{0 . 0 0 1}$ \\
\hline
\end{tabular}

survey, the same number of impacts due to longline and trawl net was recorded; however, the impacts due to longlines were significantly related to a geographic site characterized by coral 

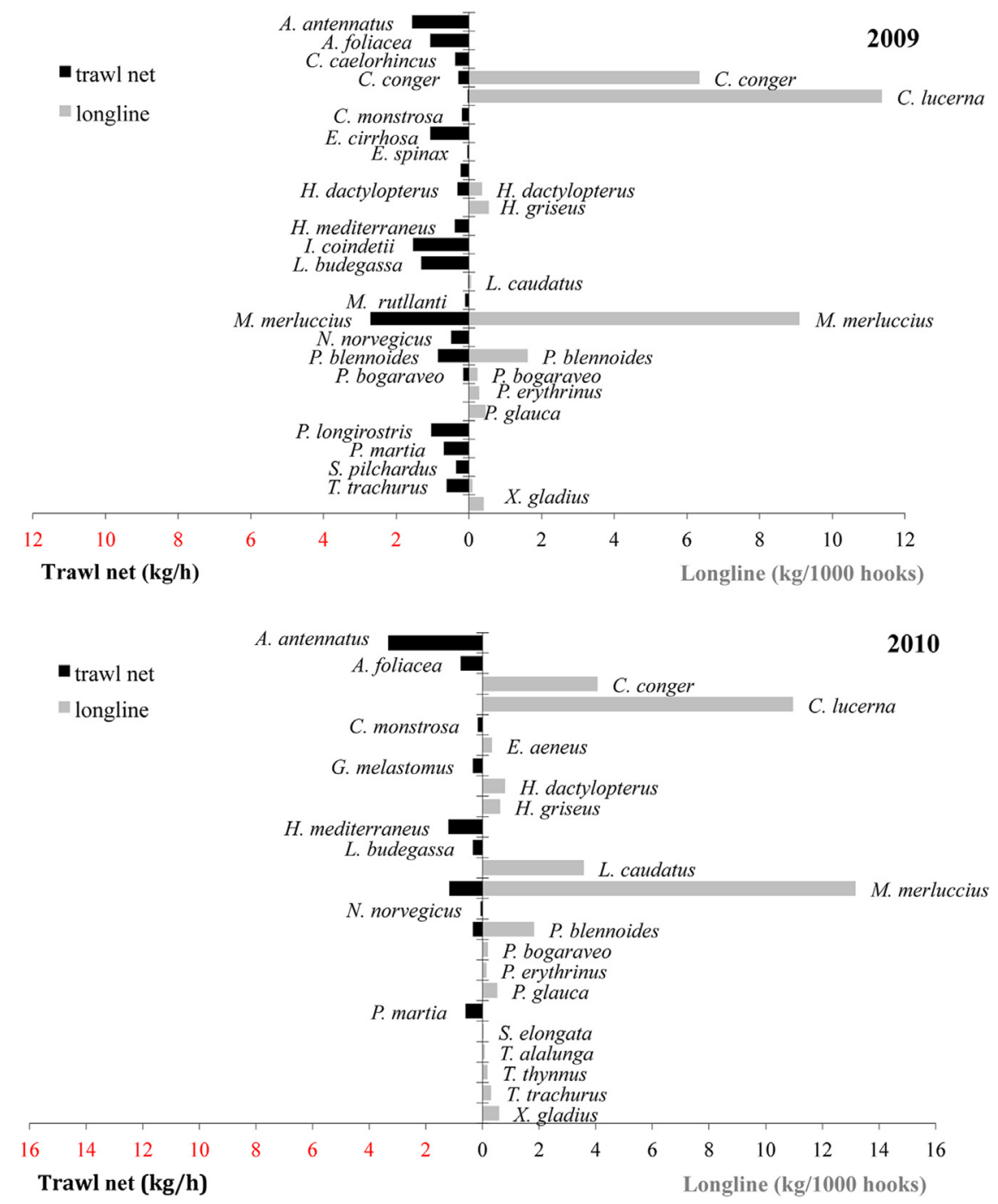

Fig. 7. Average CPUE (kg/h and kg/1000 hooks) of the most abundant species collected in the Santa Maria di Leuca fishery during the "Observers' Program" in 2009 and 2010.

Table 6

Number of vessels per year and fishing technique (trawlers $=\mathrm{OTB}$; longliners $=\mathrm{LLS}$ ) recorded in the Gallipoli and SML fisheries by VMS.

\begin{tabular}{llc}
\hline \multirow{2}{*}{ Year } & \multicolumn{2}{l}{ Metiér } \\
\cline { 2 - 3 } & OTB & LLS \\
\hline 2008 & 44 & 1 \\
2009 & 44 & 1 \\
2010 & 61 & 1 \\
2011 & 51 & 7 \\
2012 & 48 & 2 \\
2013 & 43 & 1 \\
\hline
\end{tabular}

mounds (MS06) while those from trawl nets were significantly related to fine-grained sediments (Table 2). The presence of waste was observed to be rather widespread in the examined area as the number of disposals was not significantly related to either the geographic site or the typology of macrohabitat. Plastic was the most widespread waste and the number of plastic materials was significantly related to the LCF macrohabitat (Table 2).

Observations on the anthropogenic impact in the SML CWC province have been recently reported by Savini et al. (2014). These authors refer to data collected during 2004 using three MGS video cameras for MS04, MS06 and MS08 geographic sites and during
2006 using the MARUM ROV "QUEST 4000" (Freiwald et al., 2009) for another geographic site ("Reef $A B C$ "). Although these authors reported a different classification for both macrohabitats and impacts, they revealed the greatest number of impacts, mostly due to fishing line and waste, in the MS06 geographic site, as in the present study. Moreover, they identified trawling traces exclusively within mud-dominated sediments and the greatest abundance of waste, mostly represented by plastic, in coral-dominated habitats, as in the present study.

In our opinion, the distribution of trawl net impact is due to the typology of this fishing gear which requires a regular soft bottom to fish properly while the distribution of longline impact should be mostly related to coral mounds which seem to influence the distribution of benthopelagic fish fauna and valuable commercial species, such as the blackspot seabream, in the examined area (D’Onghia et al., 2010, 2011, 2012). Thus, fishing lines can be found entangled on coral branches, coral fragments and boulders, as well as dispersed by strong bottom currents on different types of bottom in mound and intermound areas. However, the longline impacts reported in the present study and regarding different macrohabitats (Table 2) refer to observations carried out in May 2005, before the FRA establishment. Although the VMS data related to longliners indicate no fishing activity in the FRA from 2008 to 2013, it would be necessary a video check of the present 

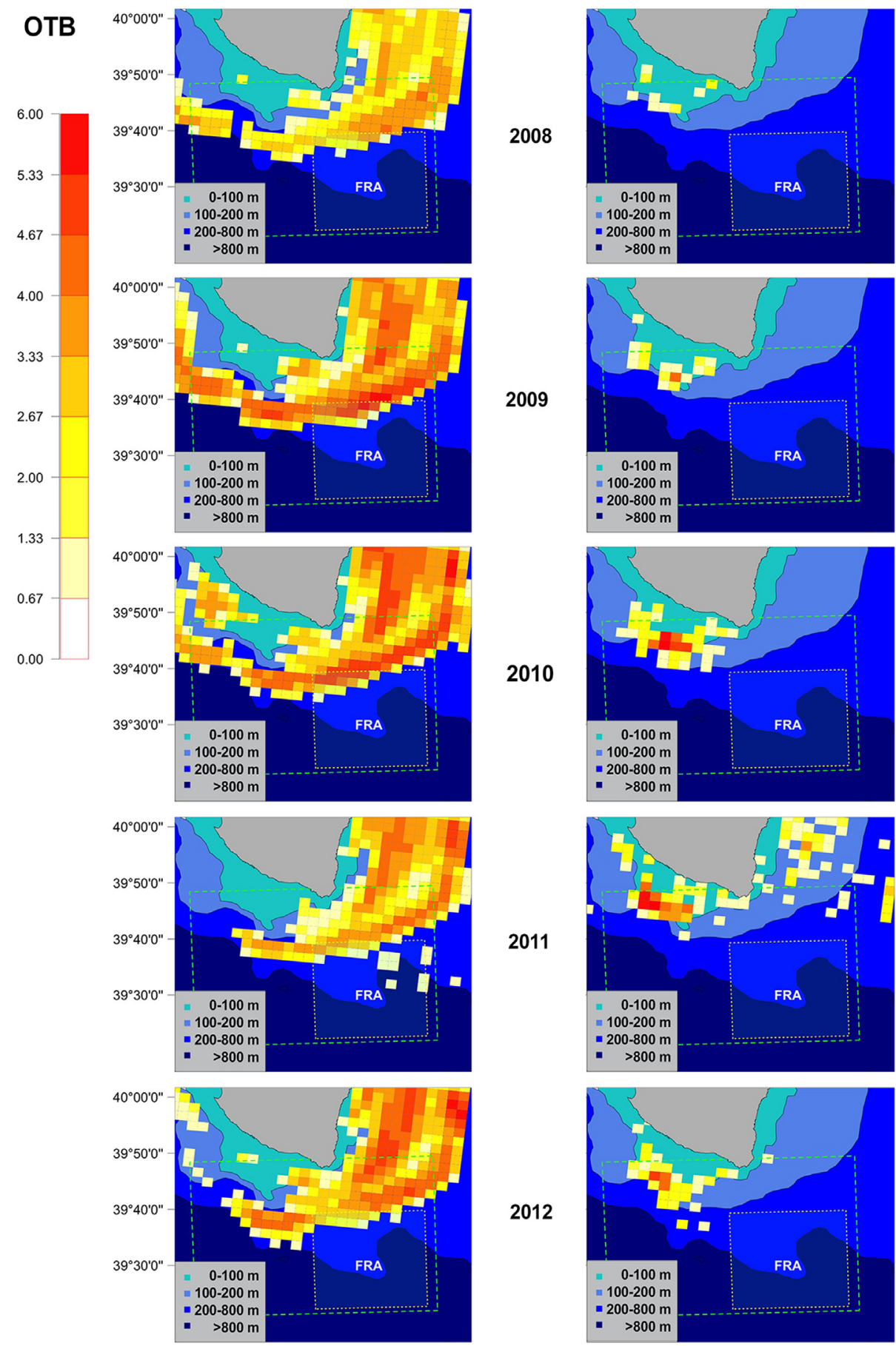

\section{LLS}
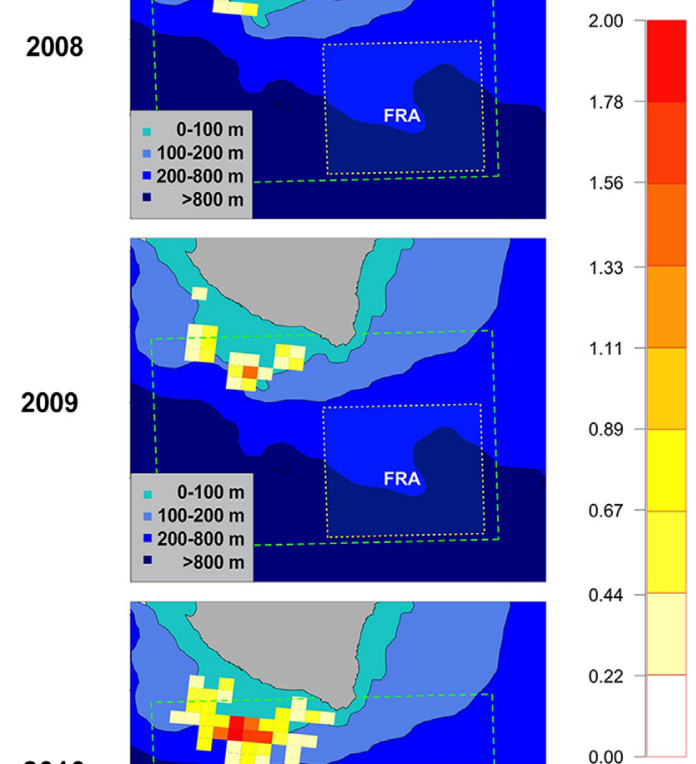

2010

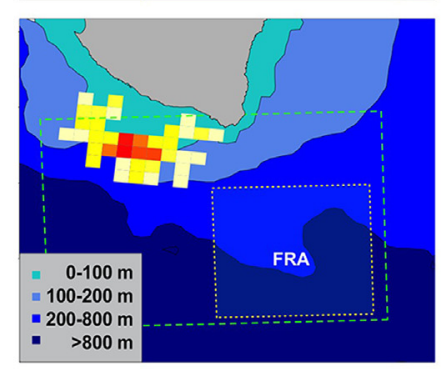

0.00

2011

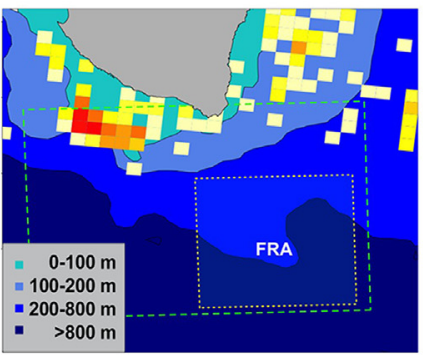

2012
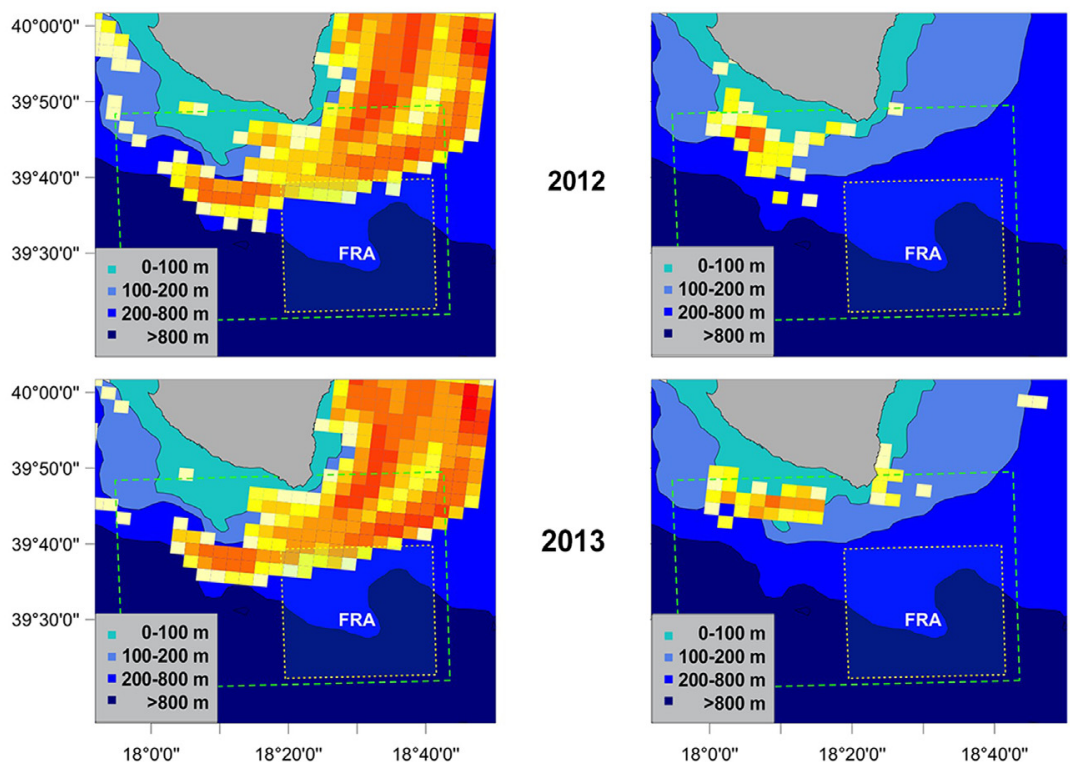

Fig. 8. Spatial representations of the fishing effort (log transformed number of fishing hours) obtained from VMS data of trawlers (OTB) and longliners (LLS) in the Gallipoli and SML fisheries. 
situation, even because VMS data for trawling indicate fishing exploitation inside the FRA for the same period.

The distribution of plastic, glass bottles, metal cans and nylon rope in the examined area, can be due both to fishing vessels and ships that sail across the Mediterranean, although the disposal of all litter (except food waste) is prohibited in this basin (Galil et al., 1995). In agreement with Galgani et al. (1996) and Savini et al. (2014), the high abundance of plastic bags in LCF habitat could be probably related to the "trapping effect" of coral branches on light material moved by bottom currents.

The fishing effort of longliners was significantly greater outside the FRA, because longlines can catch on the shelf valuable commercial species, such as $M$. merluccius and C. lucerna, and this latter has never been collected inside the coral area (D'Onghia et al., 2010, 2012). Even though some valuable commercial species, such as $P$. bogaraveo and $H$. dactylopterus, could be caught with greater abundance and sizes in the FRA (D'Onghia et al., 2010, 2012), this is distant from the coast and a thicker longline would need to be used since coral areas are very rough grounds and can basically tear the thinner longlines.

Also trawling effort was significantly greater outside the FRA; however, trawling took also place inside the fisheries restricted area as indicated by both the observers' program and VMS data. This is due to the fact that the most important fishery resources captured by trawling, the deep-water shrimps $A$. antennatus and $A$. foliacea, are distributed on the slope, between 300 and $800 \mathrm{~m}$, a depth range inside the FRA. Indeed, fishing operations by trawlers occur in the depth range of the highest biomass and sizes of deepwater shrimps (D'Onghia et al., 2005, 2009). Moreover, fishing operations by trawling very close to or even inside the northward limit of the FRA seem to be adopted with the aim of obtaining greater catches and a greater number of large specimens of fish species which find refuge in the coral area. In fact, several commercial species can be collected with greater abundance inside the coral area than outside (D'Onghia et al., 2010, 2012). Thus, both the observers' program and VMS data proved that trawlers still often fish inside the FRA.

The coral by-catch was only due to trawling during 2009 most probably because trawling was also carried out only during this year in the upper part of a canyon located in the SML CWC province at west of the FRA and characterized by the presence of corals (see the easternmost red dots in Fig. 4). However, we cannot exclude that coral by-catch also occurred during 2010 but it was not reported by fishermen in relation to the increased conversation with researchers on the importance of CWC for the deep-sea ecosystem and the relevant fishery resources. In addition, this could explain the change of the fishing time of trawlers reported by fishermen from the deeper depth stratum of $500-800 \mathrm{~m}$ towards the shallower of 200-500 m between 2009 and 2010 .

Considering the coral by-catch recorded during the observers' program and the fishing effort distribution recorded using VMS, trawling seems to be the main cause of both indirect and direct fishing impact in the FRA. Since trawling can be carried out on muddy bottoms within intermound areas, the indirect impact could be due to the alterations of the hydrodynamic and sedimentary conditions as well as to the increase in sediment suspension which could affect corals and associated benthic species in neighboring coral mounds (Rogers, 1999; Buhl-Mortensen et al., 2010; Puig et al., 2012; Purser, 2015 and references therein). The direct impact is due to the mechanical breakage proved through coral by-catch during 2009.

The direct effect of fishing on the demersal resources has been assessed for several stocks in the Northern Ionian Sea (e.g. D'Onghia et al., 1995, 1998, 2005; Maiorano et al., 2010) but the indirect effect of habitat degradation upon stocks is still unknown. Considering the role of the SML coral province and the FRA as a partial refuge from fishing, the fishing activity in this sensitive area can cause both direct effects of fishing on the stocks and indirect effects of fishing on the habitat (and probably direct as in 2009), which then impact upon stocks (Armstrong and Falk-Petersen, 2008; Armstrong et al., 2009). Indeed, overexploitation and marine habitat loss are the main human impacts presently occurring throughout the Mediterranean Sea (Coll et al., 2010). The morphology of the upper continental slope could be altered and the habitat complexity could be markedly reduced by intensive bottom trawling, producing comparable effects on the deep sea floor to those generated by agricultural ploughing on land (Puig et al., 2012).

As reported in the introduction, an FRA has been established in the SML CWC province in order to forbid fishing with towed dredges and bottom trawl nets specifically to protect the coral mounds. The GFCM recommends members to notify the appropriate authorities in order to protect this ecosystem from the impact of any other activities jeopardizing conservation of the features that characterize this particular habitat. Furthermore, the SML CWC province is also among the areas that have been selected by a majority of the conservation initiatives and is, consequently, an area with a strong international consensus for conservation objectives (Micheli et al., 2013). de Juan and Lleonart (2010) report that the establishment of a network of Marine Protected Areas (MPAs) for 12 Mediterranean sites in international waters, including the SML coral province, strictly controlled by the existing management bodies (i.e. GFCM and International Commission for Conservation of Atlantic Tunas, ICCAT) and with the support of Non Governative Organizations (NGOs) seems the most feasible measure for adopting an EAF in the Mediterranean. Identification of threats to biodiversity, habitats and ecosystem functions is crucial in MPAs planning (Giakoumi et al., 2012). Since fishing affects the whole ecosystem and not only the target species, the idea of MPAs as fishery management tools has gained worldwide attention with developing interest in EAF. One of the 12 principles of the ecosystem approach listed by the Convention on Biological Diversity is that the EAF should seek the appropriate balance between conservation and use of biological diversity (Cochrane and de Young, 2008). de Juan and Lleonart (2010) add that MPAs must apply real and effective limitations to fishing activities and must be linked to a monitoring program to control their long-term operation. Cochrane and de Young (2008) report that measures of monitoring, control and surveillance vary greatly throughout the Mediterranean and are not applied on the high seas. As reported in UNEP-MAP-RAC/SPA (2011), several constraints exist to effective implementation of the Specially Protected Area protocol of the Barcelona Convention beyond national jurisdiction. Indeed, the present work seems to indicate that the different international measures directed to the Mediterranean and regarding the SML coral province, specifically the FRA, are not effective in conserving the coral habitat and managing the whole ecosystem, including fishery resources. A similar problem has already been reported for the Pelagos Sanctuary for the conservation of Mediterranean marine mammals in the North-western Mediterranean Sea (Nortarbartolo di Sciara, 2009). Most of the SML coral province, and consequently the FRA, is beyond the 12 nautical mile territorial waters. However, this high seas FRA is relatively near to the coast, rendering access easy and essentially open. Indeed, habitat and biodiversity conservation problems also occur in coastal waters throughout the Mediterranean Sea (e.g. Fraschetti et al., 2011).

In the Mediterranean, in addition to the GFCM, the Regional Activity Centre for Specially Protected Areas (RAC/SPA) of the Barcelona Convention and the Secretariat of the Agreement on the Conservation of Cetaceans in the Black Sea, Mediterranean Sea and Contiguous Atlantic Area (ACCOBAMS) have among their mandates the development of MPAs and other spatial based management measures to achieve several objectives of their programs and 
strategies. Considering their respective roles and prerogatives regarding MPAs these Regional Organizations engaged in a collaboration process aimed at promoting the exchange of information and experiences and ensuring a high level of harmonization of their relevant programs. Furthermore, the EU Marine Strategy Framework Directive (MSFD) should represent a new tool to support EAF within the Mediterranean. The MSFD is the environmental pillar of the Union's future Maritime Policy which aims to achieve good environmental status in all of the EU's marine waters by 2020 and to protect the resource base upon which marine-related economic and social activities depend (Grehan et al., 2009). This directive specifically calls for the establishment of a network of MPAs in European waters (Long, 2011).

Therefore, if a better conservation and more effective management of the SML CWC province (including the FRA) does not occur in the near future, it will not be due to the lack of knowledge on the habitat and related resources as well as human uses and impacts, but exclusively to weak and inadequate policy mechanisms and enforcement within a fragmented geopolitical scenario characterizing the Mediterranean basin.

A clear management mandate should start by considering both human and financial resources. Indeed, conservation planning should also take into account socio-economic aspects related to the uses of a certain area and the associated cost of excluding such uses (Micheli et al., 2013 and references therein). In the present case, according to Roberts and Hawkins (2000), either effort should be made to educate and persuade local people of the need to protect CWC ecosystem, or failing this, some form of compensation might be offered to those fishermen most directly impacted by the restriction due to the FRA over the short-term. Public awareness, stakeholder involvement and a credible system of monitoring, control and surveillance will be fundamental to meet the conservation objectives of the SML CWC province biodiversity jointly with an ecosystem-based fishery management approach.

\section{Acknowledgments}

This study benefited from video recorded during the FIRB 'APLABES' (Apulian PLAteau Bank Ecosystem Study) using the RV 'Universitatis', from an observers' program carried out as part of the EU 7FP CoralFISH project (No. 213144) and from VMS data provided by the Italian Ministero delle Politiche Agricole Alimentari e Forestali (MIPAAF) - Direzione Generale Pesca. The authors acknowledge the RITMARE project funded by the Italian Ministero dell'Istruzione, dell'Università e della Ricerca (MIUR) and the EU 7FP CoCoNet project (No. 287844).

\section{Appendix A. Supplementary material}

Supplementary data associated with this article can be found in the online version at http://dx.doi.org/10.1016/j.dsr2.2016.02.012.

\section{References}

Agresti, A., 2002. Categorical Data Analysis, Second edition. Wiley \& Sons, New York.

Armstrong, C.W., Falk-Petersen, J., 2008. Habitat fisheries interactions: a missing link? ICES J. Mar. Sci. 65, 817-821.

Armstrong, C.W., Grehan, A.J., Kahui, V., Mikkelsen, E., Reithe, S., Van Den Hove S., 2009. Bioeconomic Modeling and the Management of Cold-Water Cora Resources, Oceanography 22 (1), 86-91.

Angeletti, L., Taviani, M., Canese, S., Foglini, F., Mastrototaro, F., Argnani, A., Trincardi, F., Bakran-Petricioli, T., Ceregato, A., Chimienti, G., Macic, V., Poliseno, A 2014. New deep-water cnidarian sites in the southern Adriatic Sea. Mediterr Mar. Sci. 15 (2), 1-11.
Baillon, S., Hamel, J.-F., Wareham, V.E., Mercier, A., 2012. Deep cold-water corals as nurseries for fish larvae. Front. Ecol. Environ. 10 (7), 351-356.

Bo, M., Bava, S., Canese, S., Angiolillo, M., Cattaneo-Vietti, R., Bavestrello, G., 2014a. Fishing impact on deep Mediterranean rocky habitats as revealed by ROV investigation. Biol. Conserv. 171, 167-176.

Bo, M., Cerrano, C., Canese, S., Salvati, E., Angiolillo, M., Santangelo, G., Bavestrello, G., 2014b. The coral assemblages of an off-shore deep Mediterranean rocky bank (NW Sicily, Italy). Mar. Ecol. 35, 332-342.

Brock, R., English, E., Kenchington, E., Tasker, M., 2009. The alphabet soup that protects cold-water corals in the North Atlantic. Mar. Ecol. Prog. Ser. 397, 355-360.

Buhl-Mortensen, L, Vanreusel, A Gooday, A J, Levin, L.A, Priede, I.G, BuhlMortensen, P., Gheerardyn, H., King, N.J., Raes, M., 2010. Biological structures as a source of habitat heterogeneity and biodiversity on the deep ocean margins. Mar. Ecol. 31, 21-50.

Capezzuto, F., Carlucci, R., Maiorano, P., Sion, L., Battista, D., Giove, A., Indennidate, A., Tursi, A., D'Onghia, G., 2010. The bathyal benthopelagic fauna in the northwestern Ionian Sea: structure, patterns and interactions. Chem. Ecol. 26 (Suppl), S199-S217.

Capezzuto, F., Maiorano, P., Panza, M., Indennidate, A., Sion, L., D’Onghia, G., 2012. Occurrence and behaviour of Paromola cuvieri (Crustacea, Decapoda) in the Santa Maria di Leuca cold-water coral community (Mediterranean Sea). DeepSea Res. I 59, 1-7.

Carbonara, P., Costantino, G., Giovine, G., Lembo, G., Spedicato, M.T., Machias, A., 2003. Some aspects of the life history of Polyprion americanus (Schneider, 1801) along the coast of the North Western Ionian Sea. Biol. Mar. Mediterr. 10 (2), $102-112$.

Carlier, A., Le Guilloux, E., Olu, K., Sarrazin, J., Mastrototaro, F., Taviani, M., Clavier, J., 2009. Trophic relationships in a deep Mediterranean cold-water coral bank (Santa Maria di Leuca, Ionian Sea). Mar. Ecol. Prog. Ser. 397, 125-137.

Carlucci, R., Panza, M., Costantino, G., D’Onghia, G., 2003. Osservazioni sullo sbarcato dei gamberi rossi (Aristeus antennatus ed Aristaeomorpha foliacea) nella marineria di Gallipoli (Mar Ionio). Biol. Mar. Medit. 10 (2), 781-784.

Carlucci, R., Capezzuto, F., Maiorano, P., Sion, L., D’Onghia, G., 2009. Distribution, population structure and dynamics of the black anglerfish (Lophius budegassa) (Spinola, 1987) in the Eastern Mediterranean Sea. Fish. Res. 95, 76-87.

Cochrane, K., de Young, C., 2008. Ecosystem approach to fisheries management in the Mediterranean. United Nations Food and Agriculture Organization. Options Mediterr. Ser. 62, 71-85.

Coll, M., Piroddi, C., Steenbeek, J., Kaschner, K., Ben Rais Lasram, F., Aguzzi, J., Ballesteros, E., Bianchi, C.N., Corbera, J., Dailianis, T., Danovaro, R., Estrada, M., Froglia, C., Galil, B.S., Gasol, J.M., Gertwagen, R., Gil, J., Guilhaumon, F., KesnerReyes, K., Kitsos, M.-S., Koukouras, A., Lampadariou, N., Laxamana, E., López-Fé de la Cuadra, C.M., Lotze, H.K., Martin, D., Mouillot, D., Oro, D., Raicevich, S., Rius-Barile, J., Saiz-Salinas, J.I., San Vicente, C., Somot, S., Templado, J., Turon, X., Vafidis, D., Villanueva, R., Voultsiadou, E., 2010. The biodiversity of the Mediterranean Sea: estimates, patterns, and threats. PloS One 5 (8), e11842.

Corselli, C., 2010. The APLABES programme: physical, chemical and biological characterization of deep-water coral ecosystems from the Ionian Sea (Mediterranean). Deep-Sea Res. II 57, 323-492.

DeVogelaere, A.P., Burton, E.J., Tonatiuh, T., Clague, D.A., Tamburri, M.N., Cailliet, G. M., Kochevar, R.E., Douros, W.J., 2005. Deep-sea corals and resource protection at the Davidson Seamount, California, U.S.A. In: Freiwald, A., Roberts, J.M. (Eds.), Cold-water Corals and Ecosystems. Springer-Verlag, Berlin Heidelberg, pp. 1189-1198.

de Juan, S., Lleonart, J., 2010. A conceptual framework for the protection of vulnerable habitats impacted by fishing activities in the Mediterranean high seas. Ocean Coast. Manag. 53, 717-723.

de Juan, S., Moranta, J., Hinz, H., Barberá, C., Ojeda-Martinez, C., Oro, D., Ordines, F., Ólafsson, E., Demestre, M., Massutí, E., Lleonart, J., 2012. A regional network of sustainable managed areas as the way forward for the implementation of an Ecosystem-Based Fisheries Management in the Mediterranean. Ocean Coast. Manag. 65, 51-58.

D’Onghia, G., Mastrototaro, F., Maiorano, P., 2000. Biology of silver scabbard fish, Lepidopus caudatus (Trichiuridae), from the Ionian sea (Eastern-Central Mediterranean). Cybium 24 (3), 249-262.

D’Onghia, G., Matarrese, A., Maiorano, P., Perri, F., 1998. Valutazione di Parapenaeus longirostris (Lucas, 1846) (Crustacea, Decapoda) nel Mar Ionio. Biol. Mar. Mediterr. 5 (2), 273-283.

D’Onghia, G., Mastrototaro, F., Matarrese, A., Politou, C.-Y., Mytilineou, Ch, 2003. Biodiversity of the upper slope demersal community in the eastern Mediterranean: preliminary comparison between two areas with and without trawl fishing. J. Northw. Atl. Fish. Sci. 31, 263-273.

D’Onghia, G., Matarrese, A., Tursi, A., Maiorano, P., Panetta, P., 1995. Osservazioni sulla teutofauna epi e mesobatiale nel Mediterraneo orientale (Mar Ionio e Mar Egeo). Biol. Mar. Mediterr. 2 (2), 199-204.

D’Onghia, G., Maiorano, P., Carlucci, R., Capezzuto, F., Carluccio, A., Tursi, A., Sion, L., 2012. Comparing deep-sea fish fauna between coral and non-coral "megahabitat" in the Santa Maria di Leuca cold-water coral province (Mediterranean Sea). Plos One 7 (9), e44509.

D’Onghia, G., Maiorano, P., Sion, L., Giove, A., Capezzuto, F., Carlucci, R., Tursi, A. 2010. Effects of deep-water coral banks on the abundance and size structure of the megafauna in the Mediterranean Sea. Deep-Sea Res. II 57, 397-411.

D’Onghia, G., Capezzuto, F., Mytilineou, Ch, Maiorano, P., Kapiris, K., Carlucci, R. Sion, L., Tursi, A., 2005. Comparison of the population structure and dynamics 
of Aristeus antennatus (Risso, 1816) between exploited and unexploited areas in the Mediterranean Sea. Fish. Res. 76, 22-38.

D’Onghia, G., Indennidate, A., Giove, A., Savini, A., Capezzuto, F., Sion, L., Vertino, A., Maiorano, P., 2011. Distribution and behaviour of the deep-sea benthopelagic fauna observed using towed cameras in the Santa Maria di Leuca cold water coral province. Mar. Ecol. Prog. Ser. 443, 95-110.

D’Onghia, G., Maiorano, P., Capezzuto, F., Carlucci, R., Battista, D., Giove, A., Sion, L., Tursi, A., 2009. Further evidences of deep-sea recruitment of Aristeus antennatus (Crustacea: Decapoda) and its role in the population renewal on the exploited bottoms of the Mediterranean. Fish. Res. 95 (2-3), 236-245.

D’Onghia, G., Capezzuto, F., Cardone, F., Carlucci, R., Carluccio, A., Chimienti, G., Corriero, G., Longo, C., Maiorano, P., Mastrototaro, F., Panetta, P., Rosso, A., Sanfilippo, R., Sion, L., Tursi, A., 2015. Macro- and megafauna recorded in the submarine Bari Canyon (southern Adriatic, Mediterranean Sea) using different tools. Mediterr. Mar. Sci. 16 (1), 180-196.

Duncan, C., 2001. Offshore marine conservation, 'Darwin Mounds' and beyond. Mar. Conserv. 5, 14-15.

Durán Muñoz, P., Murillo, F.J., Sayago-Gil, M., Serrano, A., Laporta, M., Otero, I., Gómez, C. 2011. Effects of deep-sea bottom longlining on the Hatton Bank communities and benthic eco system, north-east Atlantic. J. Mar. Biol. Assoc. 91 (4), 939-952.

EC, 2002. Council regulation (EC) no. 2371/2002 of 20 december 2002 on the conservation and sustainable exploitation of fisheries resources under the Common Fisheries Policy. Off. J. Eur. Communities, 59-80, L358.

Etiope, G., Savini, A., Lo Bue, N., Favali, P., Corselli, C., 2010. Deep-sea survey for the detection of methane at the "Santa Maria di Leuca" cold-water coral mounds (Ionian Sea, South Italy). Deep-Sea Res. II 57 (5-6), 431-440.

Fabri, M.C., Pedel, L., Beuck, L., Galgani, F., Hebbeln, D., Freiwald, A., 2014. Megafauna of vulnerable marine ecosystems in French Mediterranean submarine canyons: spatial distribution and anthropogenic impacts. Deep Sea Res. II 104, 184-207.

FAO, 2009. Report of the Technical Consultation on International Guidelines for the Management of Deep-sea Fisheries in the High Seas, Rome. 4-8 February and 25-29 August 2008, FAO Fisheries and Aquaculture Report, 881, pp. 86.

Fosså, J.H., Mortensen, P.B., Furevik, D.M., 2002. The deep-water coral Lophelia pertusa in Norwegian waters: distribution and fishery impacts. Hydrobiologia $471,1-12$.

Fraschetti, S., Guarnieri, G., Bevilacqua, S., Terlizzi, A., Claudet, J., Russo, G.F., Boero, F., 2011. Conservation of Mediterranean habitats and biodiversity countdown: what information do we really need? Aquat. Conserv. Mar. Freshw. Ecosyst. 21, 299-306.

Freiwald, A., Beuck, L., Rüggerberg, A., Taviani, M., Hebblen, D., 2009. The white coral community in the Central Mediterranean Sea revealed by ROV surveys. Oceanography 22 (1), 36-52.

Freiwald, A., Fosså, J.H., Grehan, A., Koslow, T., Roberts, J.M., 2004. Cold-water Coral Reefs. UNEP-WCMC. Cambridge, UK.

Galgani, F., Souplet, A., Cadiou, Y., 1996. Accumulation of debris on the deep sea floor of the French Mediterranean coast. Mar. Ecol. Prog. Ser. 142, 225-234.

Galil, B.S., Golik, A., Turkay, M., 1995. Litter at the bottom of the sea: a sea bed survey in the eastern Mediterranean. Mar. Pollut. Bull. 30, 22-24.

Garcia, S.M., Zerbi, A., Aliaume, C., Do Chi, T., Lasserre, G., 2003. The ecosystem approach to fisheries. Issue, terminology, principles, institutional foundations, implementation and outlook. FAO Fish. Tech. Pap. 443, 71.

GFCM-RAC/SPA, 2007. Report of the Transversal Workshop on Marine Protected Areas (MPAs). Salammbô, Tunisia, pp. 34.

Giakoumi, S., Mazor, T., Fraschetti, S., Kark, S., Portman, M., Coll, M., Steenbeek, J., Possingham, H., 2012. Advancing marine conservation planning in the Mediterranean Sea. Rev. Fish. Biol. Fish. 22 (4), 943-949.

Gori, A., Orejas, C., Madurell, T., Bramanti, L., Martins, M., Quintanilla, E., Marti-Puig, P., Lo Iacono, C., Puig, P., Requena, S., Greenacre, M., Gili, J.M., 2013. Bathymetrical distribution and size structure of cold-water coral populations in the Cap de Creus and Lacaze-Duthiers canyons (northwestern Mediterranean). Biogeosciences 10, 2049-2060.

Grehan, A.J., Unnithan, V., Olu, K., Opderbecke, J., 2005. Fishing impacts on Irish deep-water coral reefs: making a case for coral conservation. Am. Fish. Soc. Symp. 41, 819-832.

Grehan, A.J., van Den Hove, S., Armstrong, C.W., Long, R., Rensburg, T.V., Gunn, V., Mikkelsen, E., de Mol, B., Hain, S., 2009. HERMES promoting ecosystem-based management and the sustainable use and governance of deep-water resources. Oceanography 22, 154-166.

Hall-Spencer, J.M., 2001. Maerl-a spectacular Firth of Clyde habitat. In: Proceedings of the conference on the Ecology and Management of the Firth of Clyde, pp. 43-44.

Hall-Spencer, J., Allain, V., Fossa, J.H., 2002. Trawling damage to northeast Atlantic ancient coral reefs. Proc. R. Soc. Lond. Ser. B-Biol. Sci. 269, 507-511.

Henry, L.A., Navas, J.M., Hennige, S.J., Wicks, L.C., Vad, J., Murray Roberts, J., 2013. Cold- water coral reef habitats benefit recreationally valuable sharks. Biol. Conserv. $161(0), 67-70$

Hourigan, T.F., 2009. Managing fishery impacts on deep-water coral ecosystems of the USA: emerging best practices. Mar. Ecol. Prog. Ser. 397, 333-340.

Indennidate, A., Carlucci, R., Maiorano, P., Sion, L., D’Onghia, G., 2010. Fishing effort and catch composition on the boundaries of Santa Maria di Leuca deep-water coral bank. Biol. Mar. Mediterr. 17 (1), 340-341.

Lartaud, F., Pareige, S., de Rafelis, M., Feuillassier, L., Bideau, M., Peru, E., De la Vega, E., Nedoncelle, K., Romans, P., Le Bris, N., 2014. Temporal changes in the growth of two Mediterranean cold-water coral species, in situ and in aquaria. Deep-Sea Res. II 99, 64-70.
Lo Iacono, C., Orejas, C., Gori, A., Gili, J.M., Requena, S., Puig, P., Ribó, M., 2012. The habitats of the Cap de Creus continental shelf and Cap de Creus Canyon, northwestern Mediterranean. In: Baker, E., Baker, P. (Eds.), Seafloor Geomorphology as Benthic Habitat: GeoHab Atlas of seafloor geomorphic features and benthic habitats. Harris. Elsevier, London, pp. 457-469.

Long, R., 2011. Legal aspects of ecosystem-based marine management in Europe. Ocean. Yearb. 26, 417-484.

Longo, C., Mastrototaro, F., Corriero, G., 2005. Sponge fauna associated with a Mediterranean white coral bank. J. Mar. Biol. Assoc. 85, 1341-1352.

Lumsden, S.E., Hourigan, T.F., Bruckner, A.W., Dorr, G. (Eds.), 2007. The State of Deep Coral Ecosystems of the United States. NOAA Technical Memorandum CRCP-3. Silver Spring, Maryland.

Madurell, T., Orejas, C., Requena, S., Gori, A., Purroy, A., Lo Iacono, C., Sabatés, A., Dominguez-Carrió, C., Gili, J.M., 2012. The benthic communities of the Cap de Creus canyon. In: Würtz, M. (Ed.), Mediterranean Submarine Canyons: Ecology and Governance. IUCN: Gland. Switzerland and Málaga, Spain, pp. 123-132.

Maiorano, P., D’Onghia, G., Capezzuto, F., Sion, L., 2002. Life-history traits of Plesionika martia (Decapoda: Caridea) from the Eastern-Central Mediterranean Sea. Mar. Biol. 141, 527-539.

Maiorano, P., Sion, L., Carlucci, R., Capezzuto, F., Giove, A., Costantino, G., Panza, M. D'Onghia, G., Tursi, A., 2010. The demersal faunal assemblage of the NorthWestern Ionian Sea (Central Mediterranean): current knowledge and perspectives. Chem. Ecol. 26 (Suppl. 1), S219-S240.

Mastrototaro, F., Chimienti, G., Capezzuto, F., Carlucci, R., Williams, G., 2014. First record of Protoptilum carpenteri (Cnidaria, Octocorallia, Pennatulacea) in the Mediterranean Sea. Ital. J. Zool., 1-8. http://dx.doi.org/10.1080/11250003.2014.982218.

Mastrototaro, F., Maiorano, P., Vertino, A., Battista, D., Indennidate, A., Savini, A Tursi, A., D’Onghia, G., 2013. A facies of Kophobelemnon (Cnidaria, Octocorallia) from Santa Maria di Leuca coral province (Mediterranean Sea). Mar. Ecol. 34, 313-320.

Mastrototaro, F., D’Onghia, G., Corriero, G., Matarrese, A., Maiorano, P., Panetta, P. Gherardi, M., Longo, C., Rosso, A., Sciuto, F., Sanfilippo, R., Gravili, C., Boero, F., Taviani, M., Tursi, A., 2010. Biodiversity of the white coral bank off Cape Santa Maria di Leuca (Mediterranean Sea): an update. Deep-Sea Res. II 57 (5-6), $412-430$.

Micheli, F., Levin, N., Giakoumi, S., Katsanevakis, S., Abdulla, A., Coll, M., Fraschetti, S., Kark, S., Koutsoubas, D., Mackelworth, P., Maiorano, L., Possingham, H.P. 2013. Setting priorities for regional conservation planning in the Mediterranean Sea. Plos One 8 (4), e59038.

Morgan, L.E., Etnoyer, P., Scholz, A., Mertens, M., Powell, M., 2005. Conservation and management implications of deep-sea coral and fishing effort distributions in the Northeast Pacific Ocean. In: Freiwald, A., Roberts, J.M. (Eds.), Cold Water Corals and Ecosystems. Springer-Verlag, Berlin Heidelberg, pp. 1171-1187.

Mortensen, P.B., Buhl-Mortensen, L., Gordon Jr., D.C., Fader, G.B.J., McKeown, D.L., Fenton, D.G., 2005. Effects of fisheries on deep-water gorgonian corals in the Northeast Channel, Nova Scotia (Canada). In: Barnes, P.W., Thomas, J.P. (Eds.), Benthic habitats and the effects of fishing, 41. Am. Fish. Soc. Symp., Bethesda, Maryland, pp. 369-382.

Mytilineou, Ch, Smith, C.J., Anastasopoulou, A., Papadopoulou, K.N., Christidis, G. Bekas, P., Kavadas, S., Dokos, J., 2014. New cold-water coral occurrences in the Eastern Ionian Sea: Results from experimental long line fishing. Deep-Sea Res. Il 99, 146-157.

Nortarbartolo di Sciara, G., 2009. The Pelagos Sanctuary for the conservation of Mediterranean marine mammals: an iconic High Seas MPA in dire straits. In: Proceedings of the 2nd International Conference on Progress in Marine Conservation in Europe 2009. 2-6 November 2009, OZEANEUM/DMM, Stralsund Germany, pp. 1-3.

Oceana, 2011. Oceana MedNet, MPA proposal for the Mediterranean Sea. 100 reasons to reach $10 \%$. Oceana, Madrid, p. 96

Orejas, C., Ferrier-Pagès, C., Reynaud, S., Gori, A., Beraud, E., Tsounis, G., Allemand, D., Gili, J.M., 2011a. Long-term growth rates of four Mediterranean cold-water coral species maintained in aquaria. Mar. Ecol. Prog. Ser. 429, 57-65.

Orejas, C., Ferrier-Pagès, C., Reynaud, S., Tsounis, G., Allemand, D., Gili, J.M., 2011b. Experimental comparison of skeletal growth rates in the cold-water cora Madrepora oculata Linnaeus, 1758 and three tropical scleractinian corals. J. Exp. Mar. Biol. Ecol. 405, 1-5.

Orejas, C., Gori, A., Lo Iacono, C., Puig, P., Gili, J.M., Dale, M.R.T., 2009. Cold-water corals in the Cap de Creus canyon, northwestern Mediterranean: spatial distribution, density and anthropogenic impact. Mar. Ecol. Prog. Ser. 397, 37-51.

Pérès, J.M., 1985. History of the Mediterranean biota and the colonization of the depths. In: Margalef, R. (Ed.), Key Environments: Western Mediterranean. Pergamon Press, New York, pp. 198-232.

Puig, P., Canals, M., Company, J.B., Martín, J., Amblas, D., Lastras, G., Palanques, A. Calafat, A.M., 2012. Ploughing the deep sea floor. Nature 489, 286-289.

Purser, A., 2015. A time series study of Lophelia pertusa and reef megafauna responses to drill cuttings exposure on the Norwegian Margin. PloS One 10 (7), e0134076.

R Core Team, 2014. R: A Language and Environment for Statistical Computing. R Foundation for Statistical Computing, Vienna, Austria. 〈URL http://www.R-pro ject.org/ $\rangle$

Ramirez-Llodra, E., Tyler, P.A., Baker, M.C., Bergstad, O.A., Clark, M.R., Escobar, E. Levin, L.A., Menot, L., Rowden, A.A., Smith, C.R., Van Dover, C.R., 2011. Man and the last great wilderness: human impact on the deep sea. PloS One 6 (7), e22588.

Reed, J.K., 2002. Deep-water Oculina coral reefs of Florida: biology, impacts, and management. Hydrobiologia 471, 43-55. 
Relini, G., Tursi, A., 2009. Biocenosi dei coralli profondi. In: Relini, G., Giaccone, G., (Eds.), Gli habitat prioritari del protocollo SPA/BIO (Convenzione di Barcellona) presenti in Italia. Schede descrittive per l'identificazione. Biol. Mar. Medit. 16 (Suppl. 1), pp. 288-292.

Roberts, C.M., 2002. Deep impact: the rising toll of fishing in the deep sea. Trends Ecol. Evol. 17, 242-245.

Roberts, C.M., Hawkins, J.P., 2000. Fully-protected marine reserves: a guide. WWF Endangered Seas Campaign, 1250 24th Street, NW, Washington, DC 20037, USA and Environment Department, University of York, York, YO10 5DD, pp. 131

Roberts, J.M., Harvey, S.M., Lamont, P.A., Gage, J.D., 2000. Seabed photography, environmental assessment and evidence for deep-water trawling on the continental margin west of the Hebrides. Hydrobiologia 44, 173-183.

Roberts, J.M., Wheeler, A., Freiwald, A., Cairns, S.D., 2009. Cold-Water Corals: The Biology and Geology of Deep-Sea Coral Habitats. Cambridge University Press, Cambridge.

Rogers, A.D., 1999. The biology of Lophelia pertusa (Linnaeus, 1758) and other deepwater reef-forming corals and impacts from human activities. Int. Rev. Hydrobiol. 84, 315-406.

Russo, T., Parisi, A., Cataudella, S., 2011a. New insights in interpolating fishing tracks from VMS data for different métiers. Fish. Res. 108, 184-194.

Russo, T., Parisi, A., Prorgi, M., Boccoli, F., Cignini, I., Tordoni, M., Cataudella, S. 2011b. When behaviour reveals activity: inferring fishing métier from VMS data by artificial neural network. Fish. Res. 111, 53-64.

Russo, T., D'Andrea, L., Parisi, A., Cataudella, S., 2014. VMSbase: an R-package for VMS and logbook data management and analysis in fisheries ecology. PloS One 9 (6), e100195.

Russo, T., Parisi, A., Cataudella, S., 2013. Spatial indicators of fishing pressure: preliminary analyses and possible developments. Ecol. Indic. 26, 141-153.

Sampaio, I., Braga-Henriques, A., Pham, C. Ocaña, O., de Matos, V., Morato, T. Porteiro, F.M., 2012. Cold-water corals landed by bottom longline fisheries in the Azores (north-eastern Atlantic). J. Mar. Biol. Assoc. http://dxdoi.org/10.1017/ S0025315412000045

Savini, A. Vertino, A., Marchese, F. Beuck, L. Freiwald, A, 2014. Mapping coldwater coral habitats at different scales within the northern Ionian Sea (central Mediterranean): an assessment of coral coverage and associated vulnerability. PloS One 9 (1), e87108. http://dx.doi.org/10.1371/journal.pone.0087108.

Söffker, M., Sloman, K.A., Hall-Spencer, J.M., 2011. In situ observations of fish associated with coral reefs off Ireland. Deep-Sea Res. I 58, 818-825.
Taviani, M., Remia, A., Corselli, C., Freiwald, A., Malinverno, E., Mastrototaro, F., Savini, A., Tursi, A., 2005. First geo-marine survey of living cold-water Lophelia reefs in the Ionian Sea (Mediterranean basin). Facies 50, 409-417.

Tursi, A., D’Onghia, G., 1992. Cephalopods of the Ionian Sea (Mediterranean Sea). Oebalia XVIII, 25-43.

Tursi, A., Matarrese, A., D'Onghia, G., Sion, L., Maiorano, P., 1994. The yield per recruit assessment of hake (Merluccius merluccius L. 1758) and red mullet (Mullus barbatus L. 1758) in the Ionian Sea. FAO Fish. Rep. (Suppl. 533), 127-142.

Tursi, A., Maiorano, P., Basanisi, M., Perri, F., 1998. Distribuzione e struttura di popolazione di Nephrops norvegicus (Linneo, 1758) nel Mar Ionio settentrionale. Biol. Mar. Mediterr. 5 (1), 729-733.

Tursi, A., Mastrototaro, F., Matarrese, A., Maiorano, P., D’Onghia, G., 2004. Biodiversity of the white coral reefs in the Ionian Sea (Central Mediterranean). Chem. Ecol. 20 (Suppl. 1), S107-S116.

UNEP-MAP-RAC/SPA, 2009. Synthesis of National Overviews on Vulnerability and Impacts of Climate Change on Marine and Coastal Biological Diversity in the Mediterranean Region. By Pavasovic, A., Cebrian, D., Limam, A., Ben Haj, S., Garcia- Charton, J.S. (Eds.), RAC/SPA, Tunis, pp. 76.

UNEP-MAP-RAC/SPA, 2010. The Mediterranean Sea Biodiversity: state of the ecosystems, pressures, impacts and future priorities. By Bazairi, H., Ben Haj, S. Boero, F., Cebrian, D., De Juan, S., Limam, A., Lleonart, J., Torchia, G., Rais, C. (Eds.), RAC/SPA, Tunis, pp. 100.

UNEP-MAP-RAC/SPA, 2011. Note on the establishment of marine protected areas beyond national jurisdiction or in areas where the limits of national sovereignty or jurisdiction have not yet been defined in the Mediterranean Sea. By Scovazzi, T. (Ed.), RAC/SPA, Tunis, pp. 54.

Vertino, A Savini, A Rosso, A Di Geronimo, I, Mastrototaro, F Sanfilippo, R. Gay, G., Etiope, G., 2010. Benthic habitat characterization and distribution from two representative sites of the deep-water SML coral mound province (Mediterranean). Deep-Sea Res. II 57, 380-396.

Wheeler, A.J., Bett, B.J., Billett, D.S., Masson, D.G., Mayor, D., 2005. The Impact of Demersal Trawling on Northeast Atlantic Coral Habitats: the case of the Darwin Mounds. 41. Am. Fish. Soc. Symp, United Kingdom, pp. 807-817.

Wienberg, C., Hebbeln, D. Fink, H.G., Mienis, F., Dorschel, B., Vertino, A López Correa, M., Freiwald, A., 2009. Scleractinian cold-water corals in the Gulf of Cádiz - first clues about their spatial and temporal distribution. Deep-Sea Res. I 56, 1873-1893. 